\title{
EEG Markers in Emotionally Unstable Personality DisorderA Possible \\ Outcome Measure for Neurofeedback: A Narrative Review
}

\author{
Boland, Cailin
}

http://hdl.handle.net/10026.1/17183

$10.1177 / 1550059420937948$

Clinical EEG and Neuroscience

SAGE Publications

All content in PEARL is protected by copyright law. Author manuscripts are made available in accordance with publisher policies. Please cite only the published version using the details provided on the item record or document. In the absence of an open licence (e.g. Creative Commons), permissions for further reuse of content should be sought from the publisher or author. 
See discussions, stats, and author profiles for this publication at: https://www.researchgate.net/publication/342784682

\section{EEG Markers in Emotionally Unstable Personality Disorder-A Possible Outcome Measure for Neurofeedback: A Narrative Review}

Article in Clinical EEG and neuroscience: official journal of the EEG and Clinical Neuroscience Society (ENCS) · July 2020

DOI: $10.1177 / 1550059420937948$

CITATION

1

9 authors, including:

Cailin Boland

Ireland's Health Services

4 PUBLICATIONS 26 CITATIONS

SEE PROFILE

Katy Oak

Royal Cornwall Hospitals NHS Trust

9 PUBLICATIONS 33 CITATIONS

SEE PROFILE

Some of the authors of this publication are also working on these related projects:

Project Functional Neuroscience View project

Project Prescribing antiepileptic drugs for people with epilepsy and intellectual disability View project
READS

54

(2) Virupakshi Jalihal

2. M. S. Ramaiah Medical College

9 PUBLICATIONS 144 CITATIONS

SEE PROFILE

Brendan Mclean

Royal Cornwall Hospitals NHS Trust

79 PUBLICATIONS 2,175 CITATIONS

SEE PROFILE 


\section{Clinical EEG and Neuroscience}

\section{EEG markers in Emotionally Unstable Personality Disorder a possible outcome measure for neurofeedback - A Narrative Review}

\begin{tabular}{|c|c|}
\hline Journal: & Clinical EEG \& Neuroscience \\
\hline Manuscript ID & EEG-19-0116.R2 \\
\hline Manuscript Type: & Review \\
\hline Keywords: & $\begin{array}{l}\text { adults, biofeedback, EEG, electroencephalogram (EEG), Evoked } \\
\text { potential, neurofeedback }\end{array}$ \\
\hline Abstract: & $\begin{array}{l}\text { Objectives - } \\
\text { There is growing evidence for the use of biofeedback (BF) in affective } \\
\text { disorders, dissocial personality disorder and in children with histories of } \\
\text { abuse. EEG markers could be used as neurofeedback in emotionally } \\
\text { unstable personality disorder (EUPD) management especially for those at } \\
\text { high risk of suicide when emotionally aroused. This narrative review } \\
\text { investigates the evidence for electroencephalogram (EEG) markers in } \\
\text { EUPD. } \\
\text { Methods - } \\
\text { PRISMA guidelines were used to conduct a narrative review. A structured } \\
\text { search method was developed and implemented in collaboration with an } \\
\text { information specialist. Studies were identified via three electronic } \\
\text { database searches of Medline, Embase and psychINFO. A predesigned } \\
\text { inclusion/exclusion criterion was applied to selected papers. A thematic } \\
\text { analysis approach with five criteria was used. } \\
\text { Results - } \\
\text { From an initial long list of } 5250 \text { papers, } 229 \text { studies were identified and } \\
\text { screened, of which } 44 \text { met at least three of the predesigned inclusion } \\
\text { criteria. No research to date investigates EEG-based neurofeedback in } \\
\text { EUPD. A number of different EEG biomarkers are identified but there is } \\
\text { poor consistency between studies. } \\
\text { Conclusions - } \\
\text { The findings heterogeneity may be due to the disorder complexity and } \\
\text { the variable EEG related parameters studied. An alternative explanation } \\
\text { may be that there are a number of different neuromarkers, which could } \\
\text { be clustered together with clinical symptomatology, to give new sub- } \\
\text { domains. Quantitative EEGs in particular may be helpful to identify more } \\
\text { specific abnormalities. EEG standardization of neurofeedback protocols } \\
\text { based on specific EEG abnormalities detected may facilitate targeted use } \\
\text { of neurofeedback as an intervention in EUPD. }\end{array}$ \\
\hline
\end{tabular}

\section{SCHOLARONE" Manuscripts}




\section{EEG markers in Emotionally Unstable Personality Disorder; a possible outcome measure for neurofeedback - A Narrative Review}

Dr Cailín Boland ${ }^{1,2}$, Dr Virupakshi Jalihal ${ }^{3}$, Ms Catriona Organ ${ }^{4}$, Mrs Katy Oak ${ }^{4}$, Dr Brendan McLean $^{4}$, Dr Richard Laugharne ${ }^{5,6}$, Dr Wessel Woldman ${ }^{7}$, Dr Randy Beck ${ }^{8}$, Dr Rohit Shankar $5,6 *$

${ }^{1}$ Saint James's hospital, James's street North, Dublin 3, Ireland

${ }^{2}$ Trinity College Dublin, College Green, Dublin 2, Ireland

${ }^{3}$ Ramaiah Medical College and Hospitals Bengaluru, India

${ }^{4}$ Royal Cornwall Hospitals Trust

${ }^{5}$ Cornwall Partnership NHS Foundation Trust

${ }^{6}$ Exeter Medical School

${ }^{7}$ School of Maths, Exeter University

${ }^{8}$ Institute of Functional Neuroscience, Perth, Australia

*Corresponding author:

Dr Rohit Shankar

Chygovenck, Threemilestone Industrial Estate, Truro Cornwall TR4 9LD

Email: Rohit.shankar@nhs.net

Conflict of Interest Statement: There are no conflicts of interest for any author

Word count: 4246

No funding was received to deliver this piece of work 


\section{ABSTRACT:}

Objectives -

There is growing evidence for the use of biofeedback (BF) in affective disorders, dissocial personality disorder and in children with histories of abuse. EEG markers could be used as neurofeedback in emotionally unstable personality disorder (EUPD) management especially for those at high risk of suicide when emotionally aroused. This narrative review investigates the evidence for electroencephalogram (EEG) markers in EUPD.

Methods -

PRISMA guidelines were used to conduct a narrative review. A structured search method was developed and implemented in collaboration with an information specialist. Studies were identified via three electronic database searches of Medline, Embase and psychINFO. A predesigned inclusion/exclusion criterion was applied to selected papers. A thematic analysis approach with five criteria was used.

Results -

From an initial long list of 5250 papers, 229 studies were identified and screened, of which 44 met at least three of the predesigned inclusion criteria. No research to date investigates EEG-based neurofeedback in EUPD. A number of different EEG biomarkers are identified but there is poor consistency between studies.

Conclusions -

The findings heterogeneity may be due to the disorder complexity and the variable EEG related parameters studied. An alternative explanation may be that there are a number of different neuromarkers, which could be clustered together with clinical symptomatology, to 
give new sub-domains. Quantitative EEGs in particular may be helpful to identify more specific abnormalities. EEG standardization of neurofeedback protocols based on specific EEG abnormalities detected may facilitate targeted use of neurofeedback as an intervention in EUPD.

\section{KEY WORDS:}

Emotionally unstable personality disorder; Borderline personality disorder;

Electroencephalogram; Neurofeedback; Neuromodulation 


\section{INTRODUCTION:}

\section{Emotionally Unstable Personality Disorder -}

Emotionally unstable personality disorder (EUPD) is one of ten personality disorders defined in the ICD classification system. ${ }^{1}$ It is a complex disorder characterised by pervasive instability of interpersonal relationships, self-image, mood and impulsive behaviour. There is a pattern of rapid fluctuation from periods of confidence to despair, with fear of abandonment and chronic feelings of emptiness. Transient psychotic symptoms including brief delusions and hallucinations may also be present. There is a strong tendency towards suicidal thinking and self-harm. People with EUPD are at high risk of suicide with 60 to $70 \%$ attempting suicide at some point and a completed suicide rate of $10 \% .^{2,3}$

Along with psychosocial and functional impairment, EUPD is associated with significant financial cost to the healthcare system, social services and wider society, ${ }^{4,5}$ especially when in an emotional crisis or aroused state. The National Institute of Health and Clinical Excellence (NICE) guidelines for the management of EUPD advise frequent risk assessment and management, psychological treatments, medications for management of comorbidities and short-term medication use in crisis. ${ }^{6}$ However, there are few drugs or interventions recommended specifically for EUPD or the individual symptoms or behaviour associated with the disorder. Any newer or additional treatment options would be welcome in the management of EUPD, particularly for those in the aroused state.

\section{Electroencephalogram and psychopathology -}

The relationship between changes on the electroencephalogram (EEG) and psychopathology has long been recognised (Table 1$).{ }^{7-14}$ 
There is also evidence for the impact of psychotropic medications on alpha, beta, delta and theta waves of the EEG. ${ }^{11-15}$

\section{Evidence for EEG based neurofeedback in psychiatric disorders}

A study examined the relationship between distribution patterns of epileptiform discharges (ED) and clinical symptoms across affective, cognitive, and somatic domains. ${ }^{16}$ In a sample of 71 nonepileptic psychiatric patients, those with EDs appearing in homologous electrode pairs endorsed significantly fewer symptoms related to affective deregulation. Conversely, patients with isolated EDs focused to a single brain region endorsed greater affective deregulation and severe clinical symptoms. These factors suggest that a carefully recorded and analysed EEG could be used to identify neuromarkers for many non-epileptic psychiatric disorders.

Various EEG changes have been observed in psychiatric disorders. Increased slow wave activity has been demonstrated in those with depression, OCD, autism and ADHD. ${ }^{17,18}$ Posterior sharp waves have been seen in a range of psychiatric disorders. ${ }^{19}$ Applying modern network theory to EEG and fMRI studies of people with schizophrenia has shown loss of functional connectivity and increased randomness of the networks compared to controls. ${ }^{20}$ Intermittent rhythmic delta and theta activity have been shown in a range of disorders, ${ }^{21}$ and alterations in gamma synchrony have been demonstrated in schizophrenia, in particular under resting conditions and in the auditory evoked state. ${ }^{22}$ During processing of neutral stimuli, subjects with an anxiety disorder may have a shorter latency of P300 and higher amplitude of event-related potentials compared to controls. ${ }^{23}$

There is growing evidence for EEG changes in dissocial personality disorder. ${ }^{24-28}$ Gender differences in psychopathology presentation show that males under similar conditions display a higher level of externalising (including dissocial behaviour disorders) and females a higher 
level of internalising (including EUPD) symptoms, ${ }^{29-31}$ suggesting that changes evident in dissocial personality disorder may also be applicable in EUPD. Furthermore, early childhood sexual and psychological abuse and early stress have been linked to increased electrophysiological abnormalities. ${ }^{32-35}$ Such early life experiences are associated with EUPD. Thus, electrophysiological changes may also exist in EUPD.

Researchers have been examining the possibility of using biofeedback (BF) as a treatment for affective disorders, ${ }^{36,37}$ and in other areas of psychiatry ${ }^{9,38,39}$. A recent systematic review investigated various modalities of BF for psychiatric disorders. ${ }^{9}$ Of the EEG BF articles reviewed, fourteen $(70.0 \%)$ studies reported statistically significant clinical amelioration following EEG BF exposure. Mean number of sessions per study was 23.7 (range 5-69), with BF exposure lasting $28.7 \mathrm{~min}$ (range 14.6-60 min) on average per session. Different types of neurofeedback therapy were utilised in the studies including alpha regulation neurofeedback, alpha-theta regulation feedback, alpha-asymmetry regulation, theta feedback, alternating theta decrease/beta increase neurofeedback, slow cortical potential neurofeedback and qEEG (quantitative EEG) guided BF. QEEG is an emerging form of neurofeedback, which applies mathematical and statistical analysis to EEG brainwaves, and compares them to age and gender controlled databases of individuals with no known brain dysfunction. Recently qEEG neurofeedback has been used therapeutically in the treatment of dissocial personality disorder. ${ }^{40}$ QEEG guided neurofeedback has been shown to have medium size effect in improving attention and reducing behavioural, emotional and social problems of children with histories of abuse and neglect. ${ }^{41}$ Other components of neurofeedback therapy such as the number of channels used for EEGs, number and duration of neurofeedback sessions may also represent important considerations for neurofeedback protocols.

\section{Evidence for neurofeedback in EUPD and other psychiatric disorders using neuroimaging and neurofeedback training}


More recently, evidence for neurofeedback in EUPD has emerged. A proof of concept study for fMRI-based neurofeedback in complex emotional states preliminarily validates the notion that individuals can experience powerful emotional states and recruit relevant brain networks in real time using a neurofeedback tool. ${ }^{42}$ Furthermore, amygdala neurofeedback via fMRI has been associated with successful down-regulation of right dorsal amygdala activation in patients with EUPD. ${ }^{43}$ There was also evidence for reduced dissociative experiences and improvements in emotion regulation in those with EUPD. Such results demonstrate that neurofeedback may improve abnormalities found on MRI and emotion regulation in patients with EUPD. However further validation is required.

Neurofeedback therapy generally utilises specific targets dependent on the disorder. A common target of EEG neurofeedback in major depressive disorder is an increased spectral power in the alpha band on the left and a decreased spectral power in the alpha band on the right fronto-central cortex. ${ }^{39,44}$ Along with depressive disorder, EEG alpha asymmetry has also been shown in individuals with schizophrenia. ${ }^{45}$ The theta/beta protocol where the goal is to decrease brain activity in the theta band and increase brain activity in the beta band at the vertex is the most commonly used EEG-based neurofeedback therapy in ADHD. A common goal of neurofeedback for treatment of psychiatric symptoms in children with autism is to inhibit the theta-alpha ratio while enhancing beta waves. ${ }^{46}$ Theta neurofeedback training may also have potential benefits in treatment of generalized anxiety disorder. ${ }^{47}$

The growing research on EEG neurofeedback for affective disorders, ${ }^{36,37,39-44}$ dissocial personality disorder, ${ }^{40}$ and in children with histories of abuse, ${ }^{41}$ raises consideration as to whether similar evidence has been explored for EUPD. The strength of any such evidence and whether such deliberations can further specific investigation and treatments in this modality for EUPD is examined in this paper. 


\title{
Hypothesis -
}

There is evidence for fMRI neurofeedback in EUPD, but there has been no research to date which examined EEG-guided neurofeedback in EUPD. EEG-guided neurofeedback is likely to be easier to complete and can be made more widely available compared to fMRI guided neurofeedback.

\begin{abstract}
Aim -
1. This review looks to appraise the evidence to date for EEG changes in EUPD and in arousal states of EUPD

2. To identify if the evidence for EEG changes in EUPD has provided any management strategies.

3. The review aims to consider if neurofeedback using EEG changes as a potential intervention for EUPD is a viable option.
\end{abstract}

\section{METHODS:}

The protocol for this review followed PRISMA guidance (appendix 3). ${ }^{48}$

\section{Search strategy and selection criteria -}

References for this review were identified through searching Medline, PsycInfo and Embase using the search terms "EUPD" and "arousal" and "EEG" along with associated terms as per the search terms in Appendix 1. All articles available up until the final database search in February 2018 which had an English language translation available, were included. The search was conducted by two authors and independently verified by a third author.

After removal of duplicates, articles that were not relevant to the review were removed following review by two authors i.e. not referring to electrophysiological investigation/ 
biological markers in personality disorder, affective disorders, general psychopathology or associated terms. Two authors then applied the following prearranged inclusion criteria to all abstracts;

1) The article refers to EUPD / Borderline Personality Disorder (BPD) as the primary diagnosis

2) Must be a case-control/ cohort/ cross sectional study or higher on the hierarchy of evidence.

3) The population under investigation were all over 18 years of age

4) EEG was the only or main investigation of the study and the article referred to EUPD.

5) The article refers to EEG changes during emotional fluctuations.

Articles fulfilling less than three of the inclusion criteria were excluded. Reference lists of potentially eligible papers were manually searched for additional citations and a grey literature search was performed. A second author confirmed included studies and a final list of included articles was developed, as per pathway 1 (see appendix 1 and 2 for full search outline).

\section{RESULTS:}

Following the database search, 5250 studies were assessed for eligibility. An additional 155 studies were included following a search of the grey literature, reference lists and checking whether eligible studies were cited elsewhere. Articles were excluded at each stage as per Pathway 1 and methods (as above). Of the 44 articles which met three or more criteria, two papers met five criteria, ${ }^{49,50} 26$ papers met four criteria, ${ }^{51-76}$ and 16 papers met three criteria. ${ }^{34,41,79-88,90,93}$ 
Data on study size, population/ problem, intervention, comparisons, outcomes, setting and bias were examined. Diagnostic system used and use of sub domains of EUPD i.e. impulsive vs. borderline type were also examined. The articles were sorted according to the number of criteria fulfilled in an attempt to highlight the relative importance of individual articles to our review as per the search criteria.

\section{Articles meeting Five Criteria -}

Two articles met all five search criteria (table 2). ${ }^{49,50}$

Both of these studies had control groups (with depression and healthy controls) but had only female subjects and did not control for medications or comorbidities. These two papers established "greater left cortical activation" and "higher total theta power" respectively on EEG during arousal in people with EUPD compared to those with depression and healthy controls. However both studies were of small sample size, referred to specific incidences of high arousal and provided limited evidence for the above changes. The EEG parameters that were explored were different in both studies and hence cannot be combined or compared.

\section{Articles meeting Four Criteria (Arranged into a review article, articles using standard}

\section{EEGs, sleep EEGs and evoked potentials) -}

One review article, which met four of our search criteria, was identified. Boutros et al. examined 26 articles on electrophysiological techniques in EUPD, including one review and 25 original research articles. ${ }^{51}$ The authors performed MEDLINE and PsycInfo searches between 1966 to 2000 for "biological aspects" and "BPD”. They also performed additional searches using the terms EEG, evoked potentials (EP), sleep and polysomnography (PSG) and a search of referenced articles.

The reviewers highlight a high prevalence of electrophysiological aberrations in EUPD (such as shortened REM latency on polysomnography and diminution of P300 amplitude in evoked potential studies). They also highlight the heterogeneity between articles due to ambiguity of 
diagnostic criteria and lack of control for comorbidity and pharmacotherapy. The reviewers conclude that existing literature represents a preliminary stage in the field and suggest a need for further research combining different electrophysiological test modalities. Various types of EEG were reviewed including standard scalp EEG, sleep EEG and evoked potentials. The search used was for the period 1966 to 2000 . All the studies met criteria 1,2,3 and 4, but none of the studies identified a specific EEG change due to arousal fluctuations and thus did not meet criteria five.

The following 25 papers, which met four criteria, are presented by integrating them into key themes based on the type of EEG used to aid interpretation of results.

\section{Articles using Standard EEGs -}

Eight articles, which used standard EEGs and met four search criteria, were identified (Table 3). ${ }^{52-59}$

The main findings include correlation of impulsiveness with EEG abnormalities (positive spikes in patients with high scores for impulsivity), ${ }^{52}$ diffuse slowing, ${ }^{53}$ dysrhythmias, ${ }^{54}$ nonfocal sharp waves, especially in posterior areas, ${ }^{55}$ spike-wave discharges or a clear excess of sharp waves, increased slow wave activity, ${ }^{56}$ less stable vigilance pattern with a tendency to drop to lower vigilance states, ${ }^{57}$ increased prevalence of intermittent rhythmic delta (IRDA) or theta (IRTA) activity, ${ }^{58}$ random or semi-rhythmic theta and/or delta, and abnormalities in temporal lobe areas. ${ }^{59}$ Six of the studies had control groups and four of these discussed significant EEG abnormalities in those with EUPD. However only three of the studies adequately controlled for co-morbid conditions..$^{52,55,58}$ Two studies included a healthy control group,${ }^{57,58}$ one study included a control group for those with depression, ${ }^{55}$ and one study a control group for non-EUPD personality disorders. ${ }^{52}$ Half of the studies used clinical assessment to establish diagnosis (Table 3). ${ }^{55,57-59}$

\section{Articles using sleep EEGs -}


Ten articles on sleep EEGs that met four of the search criteria were identified (Table 4). ${ }^{60-69}$ None of these articles met criteria five (i.e. refer to EEG changes between baseline and an arousal state).

The findings from sleep EEG based studies include increased REM percentage, ${ }^{60}$ increased REM density, ${ }^{60,61}$ shorter REM latency, ${ }^{60,62-66}$ (much shorter in EUPD with Depression), ${ }^{63}$ longer REM period, ${ }^{60,67,68}$ no difference in conventional polysomnography, but increased delta power in Non-REM sleep in spectral analysis, ${ }^{69}$ reduced slow wave, stage $3 \& 4$ sleep. ${ }^{67,68}$ The most frequent abnormality found in the above studies was of reduced REM latency compared to healthy controls (six out of ten studies) and in some cases compared to other control groups. However there was no difference between the EUPD and depressed groups ${ }^{64}$ or the changes were more robust in those with depression ${ }^{60}$ Nine of the studies included healthy controls as a comparison and one study did not. ${ }^{63}$ Three of the studies included patients with co-morbid depression in the sample with EUPD, ${ }^{63,64,66}$ and two of the studies included patients with a history of substance misuse. ${ }^{61,62}$ The studies discussed all had small sample sizes ( 8 - 24 patients with EUPD) and diagnosis was made with structured measures in 7 studies. ${ }^{61,62,64,66-69}$ Four of these studies ${ }^{64,66-68}$ used DIB as a diagnostic measure and clinical criteria were used in 3 studies. ${ }^{60,63,65}$ Aside from one study, ${ }^{63}$ all of the other studies had at least 10-14 days of prior psychotropic medication free period.

\section{Articles using Evoked potentials -}

7 articles using evoked potentials, which met at least four of the search criteria, were identified (Table 5). ${ }^{70-76}$

None of these studies met criteria 5 (i.e. did not refer to EEG changes between an aroused and resting state). Of the seven studies, five used structured diagnostic criteria ${ }^{70,74}$ and two relied on clinical criteria. ${ }^{75,76}$ All seven studies had healthy control groups and four studies had additional subjects with other psychiatric conditions. ${ }^{70-72,76}$ There were no comorbidities 
or at least no affective comorbid conditions in five studies, and two studies did not report on comorbidities. ${ }^{73,76}$ The studies had only ${ }^{70,74}$ or mainly ${ }^{71,73,75,76}$ female subjects, two studies were on subjects who were medication free for at least one week ${ }^{75}$ and 30 days $^{73}$ respectively, while others had mixed groups with either no medication or on various psychotropics. Four studies consistently highlight decreased amplitude and prolonged latency of P300 during oddball paradigms/ auditory discrimination tasks in those with EUPD compared to controls. ${ }^{70-72,75}$ However, these changes were shown to be similar to those seen in schizophrenia ${ }^{71}$ and schizotypal personality disorder ${ }^{72}$ One further study illustrated differences in distinct components of P300 during an oddball paradigm/ two-tone auditory detection test between those with EUPD and healthy controls. ${ }^{73}$ Such changes highlight a specific EEG abnormality in response to an unexpected stimulus. One study reported larger late positive potential (LPP) to unpleasant stimuli. ${ }^{74}$ No difference in effect of facial emotion on ERP was reported in one study. ${ }^{76}$ The studies reviewed do not investigate P300 specifically in relation to emotional fluctuations.

\section{Articles meeting 3 Criteria}

\section{Articles meeting Criteria 1, 2 and 4}

Three studies met criteria 1, 2 and 4 (Table 6). ${ }^{77-79}$ Two of these studies used structured diagnostic criteria. ${ }^{77,78}$ There were two studies (same authors in both) with EUPD-free adolescents in the control group. ${ }^{77,78}$ All three studies were on medication free subjects. One study involved people with no comorbidities, ${ }^{79}$ one had depression and conduct disorder as comorbidities, ${ }^{77}$ while another did not report significant psychiatric comorbidity. ${ }^{78}$ One study found no significant difference in wake and sleep EEGs between patients with EUPD, nonEUPD personality disorder, dysthymic disorder and "mixed psychiatric diagnosis". ${ }^{79}$ Another study examining evoked potentials showed that there were no age-related changes in P300 
amplitude (i.e. reduction in P300 amplitude with age) in adolescents with EUPD traits as compared to normal control subjects. ${ }^{77}$ These findings suggest altered brain maturation in adolescents with emerging EUPD. However, a similarly designed case control study examining evoked potentials showed contrasting findings of reduction in P300 amplitude with age in adolescents with EUPD compared to controls. ${ }^{78}$ The findings of reduced P300 amplitude in EUPD are in keeping with earlier reported findings. ${ }^{70-72,75}$

\section{Articles meeting criteria 1, 2 and 3}

Six studies met criteria 1,2 and 3 (Table 7) ${ }^{80-85}$ Of these, two studies used clinical criteria, ${ }^{80,81}$ and four used structured instruments ${ }^{82-85}$ to establish diagnosis. Five were casecontrolled studies with four studies having healthy controls ${ }^{80,82,84,85}$ and one was a cohort study. ${ }^{83}$ There were no comorbidities or comorbidities were not reported. The findings in these studies include that those with EUPD have significantly higher loudness dependence of the N1/P2 component of auditory evoked potentials, ${ }^{80}$ mean frequency on spectral analysis correlated with anxiety levels after both placebo and amphetamine challenge, ${ }^{82}$ and that standard waking scalp EEG and TSH (thyroid stimulating hormone) influence sleep EEG, neurological soft signs and post dexamethasone cortisol levels. ${ }^{83}$ Having an abnormal EEG increases the probability of patients with EUPD having less slow wave sleep, the opposite of which is seen in EUPD patients with a normal EEG. Five biological tests including TSH, standard waking scalp EEG, sleep EEG, post dexamethasone cortisol levels and neurological soft signs were shown to be interconnected and interdependent. Other findings include reduced P3 amplitudes during No-go responses in EUPD, ${ }^{84}$ enhanced activation of the orbitofrontal cortex following an unexpected reward in EUPD patients with $\mathrm{NSSI}^{85}$ and significant delay in early posterior gamma synchrony and a reduction in right hemisphere late gamma synchrony in response to salient stimuli in EUPD. ${ }^{81}$ In the final study, the authors 
conclude that EUPD is characterised by specific disturbances in neural synchrony related to core symptoms of cognitive impairment and impulsivity.

\section{Articles meeting criteria 1, 3 and 4}

One case study (Table 8) focused on QEEG changes in a patient with EUPD. ${ }^{86}$ QEEG can provide functional information necessary to facilitate neurofeedback through engaging the brain to normalize dysfunctional brain wave patterns. ${ }^{87}$ The article showed a mild to moderate increase in slow wave frequencies (theta, delta and slow alpha) in the orbital cortex, dorsomedial prefrontal and dorsolateral prefrontal cortices and a decrease of fast wave activities in the participant compared to normative data. The findings suggest a starting point for using QEEG as a means of investigating the potential role of neurofeedback in EUPD.

\section{Articles meeting criteria 2, 3 and 4}

Five studies met criteria 2, 3 and 4 (Table 9). ${ }^{34,88-91}$ Of these, three studies used clinical criteria $^{34,88,89}$ and two studies used structured instruments ${ }^{90,91}$ to make the diagnosis. All five studies were case-control studies with healthy control groups, while two studies had additional groups with other psychiatric diagnosis. ${ }^{89,91}$ Three studies did not report on medication $^{34,90,91}$ and two studies were on those receiving antidepressants/anxiolytics..$^{90,91}$ One study had depression as a comorbidity ${ }^{90}$ and others had no comorbidities. The findings in these studies included bimodal distribution of dominant frequencies and higher incidence of beta activity in psychoneurotic patients, ${ }^{88}$ smaller late positive component (LPC) amplitude, P300 latency and P300 amplitudes when making incorrect responses to emotional pictures and faces $;{ }^{90}$ there was no significant difference between groups when making correct responses to emotional cues. This article included participants who endorsed EUPD traits (i.e. endorsing a score $>7$ on the McLean Screening Instrument) ${ }^{92}$ rather than meeting full diagnostic criteria. However the authors suggest that people who meet the full diagnostic criteria are likely to exhibit larger differences in evoked-potential response than those in this 
study. Of note, the findings of decreased P300 amplitude are consistent with research reported earlier in this paper, but shorter P300 latencies contrast with previously reported findings.

A study found reduced P3 amplitude in those with treatment resistant depression and generalised anxiety disorder compared to healthy controls and those with EUPD. ${ }^{89}$ A study on children with a history of abuse found greater average left hemisphere coherence and a greater number of abnormal EEGs. ${ }^{34}$ A study found no significant difference in event-related potentials in response to a single tone between patients with EUPD, non-EUPD personality disorders and healthy controls. ${ }^{91}$

\section{Articles meeting criteria 2, 4 and 5}

One study met criteria 2,4 and 5 (Table 10) and showed evidence for qEEG-guided neurofeedback in children with histories of abuse and neglect. ${ }^{41}$ This clinical trial showed a significant reduction in scores on the Childhood Behaviour Checklist ${ }^{93}$ following qEEGguided neurofeedback. A significant link exists between abuse and neglect in early childhood and a diagnosis of EUPD. These results point towards the potential role of qEEG-guided neurofeedback for patients with EUPD.

Of the articles which met three criteria, 11 showed EEG abnormalities in those with EUPD compared to controls. Furthermore, two articles showed EEG abnormalities in children with histories of abuse and one article demonstrated EEG abnormalities in "psychoneurosis".

\section{DISCUSSION:}

We have conducted a comprehensive review illustrating the evidence to date for EEG markers in EUPD, especially in the aroused state. This paper reviewed 44 papers according to specific search criteria. Our findings indicate a variety of possible EEG changes present in EUPD. However, there were only two studies which referred to changes between baseline and a high arousal state. ${ }^{49,50}$ The EEG findings of "greater left cortical activation" in EUPD in 
response to rejection ${ }^{49}$ and "higher total theta power" in response to pain in those with BPD$\mathrm{NP}^{50}$ are not specific to EUPD; higher alpha power in the left fronto-central cortex has been demonstrated in major depressive disorder ${ }^{39,44}$ and increased theta activity has been utilised in neurofeedback therapy in ADHD, autism and anxiety. ${ }^{45-47}$ Five studies consistently highlight differences in components of P300 during oddball paradigms/ auditory discrimination tasks in those with EUPD compared to controls. ${ }^{70-73,75}$ Arousal levels have previously been shown to effect the availability of attention processes to modulate $\mathrm{P} 300,{ }^{94,95}$ suggesting a need for further investigation of $\mathrm{P} 300$ in a state of high arousal in EUPD.

More than half of the studies examining standard waking EEGs in EUPD highlighted significant EEG abnormalities compared to controls (Table 11). All these findings can potentially be seen in other disorders. ${ }^{17-22}$ Half of the sleep EEG studies identified reduced REM latency as an EEG biomarker in EUPD. However, abnormalities detected on sleep EEG cannot be used in potential EEG based neurofeedback treatments. Half of the studies on event related potentials highlight decreased amplitude and prolonged latency of P300 in those with EUPD compared to controls, similar to the potential EEG changes seen in anxiety. ${ }^{23} \mathrm{P} 300$ amplitude and latency may represent a neuromarker in EUPD.

It is also worth noting that the studies reviewed used varying protocols for type of EEG, number of channels and electrode placement. Three of the studies did not specify type of EEG used, site of electrode placement was not specified in 14 studies, 13 studies did not specify number of channels used and 24 studies did not specify whether artefacts were removed. Other limitations to the studies reviewed include small sample size, mainly female participants, medication use and the presence of comorbid disorders.

Although not consistent between studies, various EEG abnormalities in subgroups of patients with EUPD were identified. None of the EEG findings are specific to EUPD or any other specific disorders. However, if corroborated by further evidence, these findings may 
potentially be used as neuromarkers and targets for neurofeedback in the treatment of aroused states in EUPD. One possibility is that EEG neuromarkers particular to EUPD only exist whilst in a specific state (e.g. high arousal). Alternatively there may be a number of different neuromarkers which could be clustered together with subdomains of EUPD or clinical symptomatology. This may help in identifying subdomains of patients and person-centred tailored treatments for them.

There was no study to date which investigated the potential role of EEG based neurofeedback as an intervention in EUPD. However, advances in qEEG data may improve the detection of EEG abnormalities in psychiatric disorders and thus the potential for neurofeedback therapy. ${ }^{96}$ Use of neurofeedback therapy in EUPD based on these EEG markers may result in clinical amelioration of symptoms as in other psychiatric disorders. ${ }^{9}$

\section{CONCLUSION:}

Due to the limited evidence to date, specific conclusions on EEG changes during changes in arousal in EUPD or the potential mapping of EEG findings to EUPD subdomains cannot be drawn. Further study into the mapping of neuromarkers with EUPD subdomains and clinical symptomatology could define targeted use of neurofeedback as a potential intervention in this disorder. Based on the findings in this review, a checklist of EEG findings commonly found in those with EUPD has been developed (appendix 4). The mechanism of its development has been provided (appendix 5).This checklist could be used to design and conduct further studies in this area so as to confirm or rule out the identified cumulative findings as neuromarkers of EUPD. There is evidence for using neurofeedback in a number of psychiatric conditions and our review highlights a number of EEG markers in EUPD. Hence we believe that with further research verification, EEG-based neurofeedback treatment options, especially for individuals in the aroused state could be developed. 


\section{REFERENCES:}

1. World Health Organization. ICD-10: International Classification of Diseases. International Classification of Mental and Behavioural Disorder. Diagnostic Criteria for Research. World Health Organization, Geneva. 1993.

2. Leichsering F, Leibing E, Kruse J, New AS, Leweke F. Borderline Personality Disorder. Lancet. 2011; 377: 74-84.

3. Oldham JM. Borderline personality disorder and suicidality. Am J Psychiatry. 2006; 163: 20-26.

4. McCrone P, Sujith D, Patel Knapp M, Lawton-Smith S. Paying the Price. The cost of mental health care in England in 2026. King's Fund. 2008.

5. Coid J, Yang M, Bebbington P, Moran P, Brugha T, Jenkins R, Farrell M, Singleton N, Ullrich S. Borderline personality disorder: health service use and social functioning among a national household population. Psychol Med. 2009; 39: 1721-31.

6. National Institute for Health and Care. Borderline personality disorder: recognition and management. Clinical Guideline. NICE. 2009.

7. Shelley BP, Trimble MR. "All that spikes is not fits", mistaking the woods for the trees: the interictal spikes - an "EEG chameleon" in the interface disorders of brain and mind: a critical review. Clin EEG Neurosci. 2009; 245-261.

8. Abrams R, Taylor MA. Psychopathology and the electroencephalogram. Biol Psychiatry. 1980; 15: 871-8.

9. Schoenberg PL, David AS. Biofeedback for psychiatric disorders; a systematic review. Appl Psychophysiology Biofeedback. 2014; 39: 109-35.

10. Small JG, Milstein V, Sharpley PH, Klapper M, Small IF. Electroencephalographic findings in relation to diagnostic constructs in psychiatry. Biol Psychiatry. 1984; 19: 471-87.

11. Gallinat J, Mulert C, Easy G. Significance of the electroencephalogram in psychiatry. Neurologist. 2016; 87: 323-37.

12. McLoughlin G, Makeig S, Tsuang MT. In search of biomarkers in psychiatry: EEG-based measures of brain function. Neuropsychiatric Genetics. 2013; 165B: 111-21.

13. Balogh L, Czobor P. Event-related potentials associated with error detection in psychiatric disorder: literature review. Psychiatr Hung. 2010; 25: 121-32.

14. Hughes JR, John ER. Conventional and Quantitative Electroencephalography in Psychiatry. $J$ Neuropsychiatry Clin Neurosci. 1999; 11: 190-208.

15. Aiyer R, Novakovic V, Barkin RL. A systematic review on the impact of psychotropic drugs on electroencephalogram waveforms in psychiatry. Postgrad Med. 2016; 128: 656-64.

16. Zimmerman EM, Konopka LM. Preliminary findings of single and multifocused epileptiform discharges in nonepileptic psychiatric patients. Clin EEG Neurosci. 2014; 45: 285-292.

17. Cheng P, Goldschmied J, Casement M, Kim HS, Hoffmann R, Armitage R, Deldin P. Reduction in delta activity predicted improved negative affect in Major Depressive Disorder. Psychiatry Res. 2015; 228(3): 715-8.

18. Roohi-Azizi M, Azimi L, Heysieattalab S, Aamidfar M. (2017). Changes of the brain's bioelectrical activity in cognition, consciousness, and some mental disorders. Medical journal of the Islamic Republic of Iran, 31, 53. doi:10.14196/mjiri.31.53

19. Zimmermann E. Focal Sharp Waves in Psychiatric Patients: Implications for Complex Clinical Presentation. The Chicago School of Professional Psychology, ProQuest Dissertations Publishing. 2013; 3560217

20. Van Straaten EC, Stam CJ. Structure out of chaos: functional brain network analysis with EEG, MEG, and functional MRI. Eur Neuropsychopharmacol. 2013; 23: 1, 7-18. 
21. Brigo F. Intermittent rhythmic delta activity patterns. Epilepsy \& Behavior. 2011; 20: Issue 2: 254-256.

22. Gandal MJ, Edgar JC, Klook K, Siegel SJ. Gamma synchrony: towards a translational biomarker for the treatment-resistant symptoms of schizophrenia. Neuropharmacology. 2012; 62(3): 150418.

23. Gmaj B, Januszko P, Kamiński J, Drozdowicz E, Kopera M, Wolynczyk,-Gmaj D, Szelenberger W, Wojnar M. EEG source activity during processing of neutral stimuli in subjects with anxiety disorders. Acta Neurobiol Exp. 2016; 761: 75-85.

24. Calzada-Reyes A, Alvarez-Amador A, Galan-Garcia L, Valdes-Sosa M. Electroencephalographic abnormalities in antisocial personality disorder. J Forensic Leg Med. 2012; 19: 29-34.

25. Calzada-Reyes A, Alvarez-Amador A, Galan-Garcia L, Valdes-Sosa M. EEG abnormalities in psychopath and non-psychopath violent offenders. J Forensic Leg Med. 2013; 20: 19-26.

26. Calzada-Reyes A,Alvarez-Amador A. Qualitative and quantitative EEG abnormalities in violent offenders with antisocial personality disorder. J Forensic Leg Med. 2009; 16: 59-63

27. Lindberg N, Tani P, Appelberg B, Stenberg D, Naukkarinen H, Rimon R, Porkka-Heiskanen T, Virkkunen M. Sleep among habitually violent offenders with antisocial personality disorder. Neuropsychobiology. 2003b; 47: 198-205.

28. Kiehl KA, Bates AT, Laurens KR, Hare RD, Liddle PF. Brain potentials implicate temporal lobe abnormalities in criminal psychopaths. $J$ Abnorm Psychol. 2006; 443-453.

29. Eaton NR, Keyes KM, Krueger RF, Balsis S, Skodol AE, Markon KE, Grant BF, Hasin DS. An Invariant Dimensional Liability Model of Gender Differences in Mental Disorder Prevalence: Evidence from a National Sample. J Abnorm Psychol. 2012; 282-288.

30. Kramer MD, Krueger RF, Hicks BM. The role of internalizing and externalizing liability factors in accounting for gender differences in the prevalence of common psychopathological syndromes. J Psychol Med. 2008; 51-61.

31. Tina M, Morgen K, Bradley C. Exploring gender differences on internalizing and externalizing behavior among maltreated youth. Child Adolesc Soc Work. 2008; 25: 531-47.

32. Ito Y, Teicher MH, Glod CA, Harper D, Magnus E, Gelbard HA. Increased prevalence of electrophysiological abnormalities in children with psychological, physical and sexual abuse. $J$ Neuropsychiatry Clin Neurosci. 199; 5: 401-8.

33. Ito Y, Teicher MH, Glod CA, Ackerman E. Preliminary evidence for aberrant cortical development in abused children: a quantitative EEG study. J Neuropsychiatry Clin Neurosci. 1998; 10: 298-307.

34. Teicher MH, Ito Y, Glod CA, Anderson SL, Dumont N, Ackerman E. Preliminary evidence for abnormal cortical development in physically and sexually abused children using EEG coherence and MRI. Ann N Y Acad Sci. 1997; 821: 160-75.

35. Davies RK. Incest: some neuropsychiatric findings. Int J Psychiatry Med. 1979; 9: 117-21.

36. Baehr E, Rosenfeld JP, Baehr R. Clinical Use of an Alpha Asymmetry Neurofeedback Protocol in the Treatment of Mood Disorders: Follow-up study One to Five years Post Therapy. J Neurother. 2000; 11-18.

37. Rosenfeld JP, Cha G, Blair T, Gotlib IH. Operant (biofeedback) control of left-right frontal alpha power differences: Potential neurotherapy for affective disorders. Biofeedback Self Regul. 1995; 20: 241-58.

38. Arns M, Batail JM, Bioulac S, Congedo M, Daudet C, Drapier D, Fovet T, Jardri R, Le-VanQuyen M, Lotte F, Mehler D, Micoulaud-Franchi JA, Purper-Ouakil D, Vialette F, NExT group. Neurofeedback: One of today's techniques in psychiatry? Encephale. 2017; 43: 135-145.

39. Micoulaud-Franchi JA, McGonigal A, Lopez R, Daudet C, Kotwas I, Bartolomei F. Electroencephalographic neurofeedback: Level of evidence in mental and brain disorders and suggestions for good clinical practice. Neurophysiol Clin. 2015; 45: 423-33. 
40. Surmeli R, Ertem A. QEEG guided neurofeedback therapy in personality disorders: 13 Case Studies. Clin EEG Neurosci. 2009; 40: 5-10.

41. Huang-Storms L, Bodenhamer-Davis E, Davis R, Dunn J. QEEG-Guided Neurofeedback for Children with Histories of Abuse and Neglect: Neurodevelopmental Rationale and Pilot Study. $J$ Neurother. 2006; 10: 3-16.

42. Lorenzotti V, Melo B, Basílio R, Suo C, Yucel M, Tierra-Criollo CJ, Moll J. Emotion Regulation Using Virtual Environments and Real-Time fMRI Neurofeedback. Front. Neurol. 2018; 9: 390.

43. Paret C, Kluetsch R, Zaehringer J, Ruf M, Demirakca T, Bohus M, Ende G, Schmahl C. Alterations in amygdala-prefrontal connectivity with real-time fMRI neurofeedback in BPD patients. Soc Cogn Affect Neurosci. 2016; 11: 952-960.

44. Choi SW, Chi SE, Chung SY, Kim JW, Ahn CY, Kim HT. Is alpha wave neurofeedback effective with randomized clinical trials in depression? A pilot study. Neuropsychobiology. 2011;,63:43-51.

45. Gordon E, Palmer DM, Cooper N. EEG Alpha Asymmetry in Schizophrenia, Depression, PTSD, Panic Disorder, ADHD and Conduct Disorder. Clin EEG Neurosci. 2010. 41; 4: 178-83.

46. Marzbani H, Marateb HR, Mansourian M. Neurofeedback: A Comprehensive Review on System Design, Methodology and Clinical Applications. Basic Clinical Neuroscience. 2016; 7(2): 143-58.

47. Vanathy S, Sharma PSVN, Kumar KB. The efficacy of alpha and theta neurofeedback training in treatment of generalized anxiety disorder. Indian J Clin Psychol. 1998. 25; 2: 136-43.

48. Moher D, Liberati A, Tetzlaff J, Altman, DG for the PRISMA group. Preferred reporting items for systematic reviews and meta-analysis: the PRISMA statement. BMJ. 2009; 339

49. Beeney JE, Levy KN, Gatzke-Kopp LM, Hallquist, MN. EEG asymmetry in borderline personality disorder and depression following rejection. Personal Disord. 2014; 5: 178-85.

50. Russ MJ, Campbell SS, Kakuma T, Harrison K, Zanine E. EEG theta activity and pain insensitivity in self-injurious borderline patients. Psychiatry Res. 1999; 89: 201-14.

51. Boutros NN, Torello M, McGlashan TH. Electrophysiological aberrations in Borderline Personality Disorder: State of the evidence. J Neuropsychiatry Clin Neurosci. 2003; 15: 145-54.

52. Ogiso Y, Moriya N \& Ikuta N. Relationship between clinical symptoms and EEG findings in borderline personality disorder. Jpn J Psychiatry Neurol. 1993; 47: 37-46.

53. De La Fuente JM, Tugendhaft P, Mavroudakis N. Electroencephalographic abnormalities in borderline personality disorder. Psychiatry Res. 1998; 77: 131-8.

54. Cornelius JR, Brenner RP, Soloff PH. EEG abnormalities in borderline personality disorder: Specific or nonspecific. Biol Psychiatr. 1986; 21: 977-80.

55. Cowdry RW, Pickar D, Davies R. Symptoms and EEG findings in the borderline syndrome. Int $J$ Psychiatry Med. 1986; 15: 201-11.

56. Snyder S, Pitts WM. Electroencephalography of DSM-III borderline personality disorder. Acta Psychiatr Scand. 1984; 69: 129-34.

57. Hegerl U, Stein M, Mulert C, Mergi R, Olbrich S, Dichgans E, Rujescu D, Pogarell O. EEGvigilance differences between patients with borderline personality disorder, patients with obsessive compulsive disorder and healthy controls. Eur ArchPsychiatry Clin Neurosci. 2008; 258: $137-43$.

58. Van Elst LT, Fleck M, Bartels S, Altenmuller DM, Riedel A, Bubl E, Matthies S, Feige B, Perlov E, Endres D. Increased prevalence of intermittent rhythmic delta or theta activity (IRDA/ IRTA) in the electroencephalograms (EEGs) of patients with borderline personality disorder. Front Behav Neurosci. 2016; 10: 12.

59. Yerevanian BI, Schiffer RB, Mallon PM. Electroencephalographic abnormalities in borderline patients. Amer Psychol Assoc. 1985; 46.

60. Assad T, Okasha T, Okasha A. Sleep EEG findings in ICD-10 borderline personality disorder in Egypt. $J$ Affect Disord. 2002; 71: 11-8. 
61. Battaglia M, Ferini-Strambi L, Bertella S, Bajo S, Bellodi L. First-cycle REM density in neverdepressed subjects with borderline personality disorder. Biol Psychiatry. 1999; 45 (8): 1056-8.

62. Battaglia M, Ferini-Strambi L, Smirne S, Bernardeschi L, Bellodi L. Ambulatory polysomnography of never-depressed borderline subjects: A high-risk approach to rapid eye movement latency. Biol Psychiatry. 1993; 33: 326-34.

63. Bell J, Lycaki H, Jones D. Effect of pre-existing borderline personality disorder on clinical and EEG sleep correlates of depression. Psychiatry Res. 1983; 9: 115-23.

64. McNamara E, Reynolds CF 3rd, Soloff PH, Mathias R, Rossi A, Spiker D, Coble PA, Kuper DJ. EEG sleep evaluation of depression in borderline patients. Am J Psychiatry. 1984; 141: 182-6.

65. Akiskal HS, Yerevanian BI, Davis GC, King D, Lemmi H. The nosologic status of borderline personality: Clinical and polysomnographic study. Am J Psychiatry. 1985; 142: 192-8.

66. Reynolds CF 3rd, Soloff PH, Kupfer DJ, Taska LS, Restifo K, Coble PA, McNamara ME. Depression in borderline patients: a prospective EEG sleep study. Psychiatry Res. 1985; 14: 1-15.

67. De La Fuente JM, Bobes J, Morian I, Bascaran MT, Vizuete C, Linkowski P, Mendlewicz J. Is the biological nature of depressive symptoms in borderline patients without concomitant Axis I pathology idiosyncratic? Sleep EEG comparison with recurrent brief, major depression and control subjects. Psychiatry Res. 2004; 129: 65-73.

68. De La Fuente JM, Bobes J, Vizuete C, Mendlewicz J. Sleep-EEG in borderline patients without concomitant major depression: A comparison with major depressives and normal control subjects. Psychiatry Res. 2001; 105: 87-95.

69. Philipsen A, Feige B, Al-Shajlawi A. Increased delta power and discrepancies in objective and subjective sleep measurements in borderline personality disorder. J Psychiatr Res. 2005; 39: 48998.

70. Blackwood DH, St. Clair DM, Kutcher SP. P300 event-related potential abnormalities in borderline personality disorder. Biol Psychiatry. 1986; 21: 560-64.

71. Kutcher SP, Blackwood DH, St Clair D. Auditory P300 in borderline personality disorder and schizophrenia. Arch Gen Psychiatry. 1987; 44: 645-50.

72. Kutcher SP, Blackwood DH, Gaskell DF. Auditory P300 does not differentiate borderline personality disorder from schizotypal personality disorder. Biol Psychiatry. 1989; 26: 766-74.

73. Meares R, Melkonian D, Gordon E, Williams L. Distinct pattern of P3a event-related potential in borderline personality disorder. Neuroreport. 2005; 16: 289-93.

74. Marissen MA, Meuleman L, Franken IH. Altered emotional information processing in borderline personality disorder: An electrophysiological study. Psychiatry Res. 2010; 181: 226-32.

75. Drake ME Jr, Phillips BB, Pakalanis A. Auditory evoked potentials in borderline personality disorder. Clin Electroencephalogr. 1991; 22: 188-92.

76. He W, Chai H, Chen W. Facial emotion triggered cerebral potentials in treatment-resistant depression and borderline personality disorder patients of both genders. Prog Neuropsychopharmacol Biol Psychiatry. 2012; 37: 121-7.

77. Houston RJ, Ceballos NA, Hesselbrock VM. Borderline personality disorder features in adolescent girls: P300 evidence of altered brain maturation. Clin Neurophysiol. 2005; 116: 1424 32.

78. Houston RJ, Bauer LO, Hesselbrock VM. Effects of borderline personality disorder features and a family history of alcohol or drug dependence on P300 in adolescents. Int J Psychophysiol. 2004; 53: 57-70.

79. Archer RP, Struve FA, Ball JD, Gordon RA. EEG in borderline personality disorder. Biol Psychiatry. 1988; 24: 731-2.

80. Schaaf N, Mulert C, Leicht G, Karch S, Reicherzer M, Geiso CE, Koch W, Folkerts M, Juckel G, Moller HJ, Hegerl U, Pogarell O. The Loudness Dependence of Auditory Evoked Potentials in 
patients with borderline personality disorder and healthy control subjects. Pharmacopsychiatry. 2007; 40.

81. Williams LM, Sidis A, Gordon E, Meares RA. "Missing links" in borderline personality disorder: Loss of neural synchrony relates to lack of emotion regulation and impulse control. J Psychiatry Neurosci. 2006; 31: 181-8.

82. Cornelius JR, Schulz S, Brenner RP, Soloff PH, Ulrich RJ. Changes in EEG mean frequency associated with anxiety and with amphetamine challenge in BPD. Biol Psychiatry. 1988; 24: 58794.

83. De La Fuente JM, Bengoetxea E, Navarro F, Bobes J, Alarcon RD. Interconnection between biological abnormalities in borderline personality disorder: Use of the Bayesian networks model. Psychiatry Res. 2011; 186: 315-9.

84. Ruchsow M, Groen G, Kiefer M, Buchheim A, Wlter H, Martius P, Reiter M, Hermle L, Spitzer M, Ebert D, Falkenstein M. Response inhibition in borderline personality disorder: Event-related potentials in a Go/Nogo task. J Neural Transm(Vienna). 2008; 115: 127-33.

85. Vega D, Soto A, Ribas J. Orbitofrontal overactivation in reward processing in borderline personality disorder: the role of non-suicidal self-injury. Brain Imaging Behav. 2018; 12: 217 228.

86. Cohen NY. EEG correlates of borderline personality disorders. Dissertation Abst Int. 2016; 77.

87. Dermos JN. Getting started with neurofeedback. Norton Professional Books. 2005; 10110.

88. Brazier MAB, Finesinger JE, Cobb S. A contrast between the electroencephalograms of 100 psychoneurotic patients and those of 500 normal adults. Am J Psychiatry. 1945; 101: 443-448.

89. Xu S, Chai H, Hu J, Xu Y, Chen W, Wang W. Passive event-related potentials to a single tone in treatment-resistant depression, generalized anxiety disorder and borderline personality disorder patients. J Clin Neurophysiol. 2014; 31: 488-92.

90. Hill K. Borderline Personality Traits and Emotion Processing: An event-related potentials study. University of Tasmania. 2005.

91. Shen Y, Zhu M, Wang D, Hao C, Ma J, Cao Y, Cao M, Livesley WJ, Jang KL, Chen W, Shen M, $\mathrm{Xu} \mathrm{B}$, Wang W. Passive event-related potentials by a single tone in personality disorders. Soc Behav and Personality. 2008; 36: 985-998.

92. Zanarini MC, Vujanovic AA, Parachini EA, Boulanger JL, Frankenburg FR, Hennen JA screening measure for BPD: the McLean Screening Instrument for Borderline Personality Disorder (MSI-BPD). J Pers Disord. 2003; 17: 568-73.

93. Achenbach TM. Integrative guide to the $1991 \mathrm{CBCL} / 4-18$, YSR and TRF profiles. University of Vermont: Burlington. 1991.

94. Kok A. Internal and external control: a two-factor model of amplitude change of event-related potentials. Acta Psychol (Amst). 1990; 74: 203-36.

95. Pribram K, McGuinness D. Arousal, activation and effort in the control of attention. Psychol Rev. 1975; 82: 116-49.

96. Walker JE. Recent advances in quantitative EEG as an aid to diagnosis and as a guide to neurofeedback training for cortical hypofunctions, hyperfunctions, disconnections, and hyperconnections: improving efficacy in complicated neurological and psychological disorders. Appl Psychophysiol Biofeedback. 2010; 35(1): 25-7.

97. Loranger AW, Jance A, Sartorius N. Assessment and diagnosis of personality disorders; The ICD10 International Personality Disorder Examination (IPDE). Cambridge University Press. 1997.

98. Spitzer RL. Psychiatric diagnosis: Are clinicians still necessary? (LEAD standard). Compr Psychiatry. 1983; 24: 399-411.

99. Pilkonis PA, Heape CL, Ruddy J, Serrao P. Validity in the diagnosis of personality disorders: The use of the LEAD standard. Am Psychol Asso. 1991; 3: 46-54. 
100. First MB, Spitzer RL,Williams JB. Structured clinical interview for DSM-IV axis I disorders SCID-1: Clinician version, administration booklet. Am Psychiatric Pub. 1997.

101. First MB, Spitzer RL, Gibbon M, Williams JBW, Davies M, Borus J, Howes MJ, Kane J, Harrison GP Jr., Rounsaville B. Structured Clinical Interview for DSM-III-R Personality Disorders (SCID-II). Clinical Version, administration booklet. Am Psychiatric Pub. 1995.

102. Gunderson JG, Kolb JF, Austin V. The diagnostic interview for borderline patients. Am J Psychiatry. 1981; 138: 896-903.

103. American Psychiatric Association. Diagnostic and Statistical Manual of Mental Disorders (Third Edition). Am Psychiatric Assoc. 1980.

104. American Psychiatric Association Diagnostic and Statistical Manual of Mental Disorders (Third Edition Revised). Am Psychiatric Assoc. 1987.

105. Pfohl B, Blum N, Zimmerman M. Structured Interview for DSM III-R Personality SIDP-R. Dept of Psychiatry, The University of Iowa. 1989.

106. Spitzer RL, Endicott J. The Schedule for Affective Disorders and Schizophrenia. Arch Gen Psychiatry. 1978; 35: 837-44.

107. Perry JC, Klerman GL. Clinical features of the borderline personality disorder (BEFI). Am J Psychiatry. 1980. 137.

108. American Psychiatric Association. Diagnostic and statistical manual of mental disorders. DSM-IV, ${ }^{\text {th }}$ ed. Am Psych Assoc. 1994.

109. American Psychiatric Assocation. Diagnostic and statistical manual of mental disorders $\left(4^{\text {th }}\right.$ Ed. - Text Revision). Am Psych Assoc. 2000.

110. Hesselbrock M, Easton C, Bucholz KK, Schuckit M, Hesselbrock V. A validity study of the SSAGA - a comparison with the SCAN. Addiction. 1999; 94: 1361-70.

111. Millon T, Millon C, Davis R, Grossman S. Millon Clinical Multiaxial Inventory - III (Third edition). NCS Pearson Inc. 2006. 


\section{Pathway 1: Search and selection criteria}

\section{Search and elimination process}

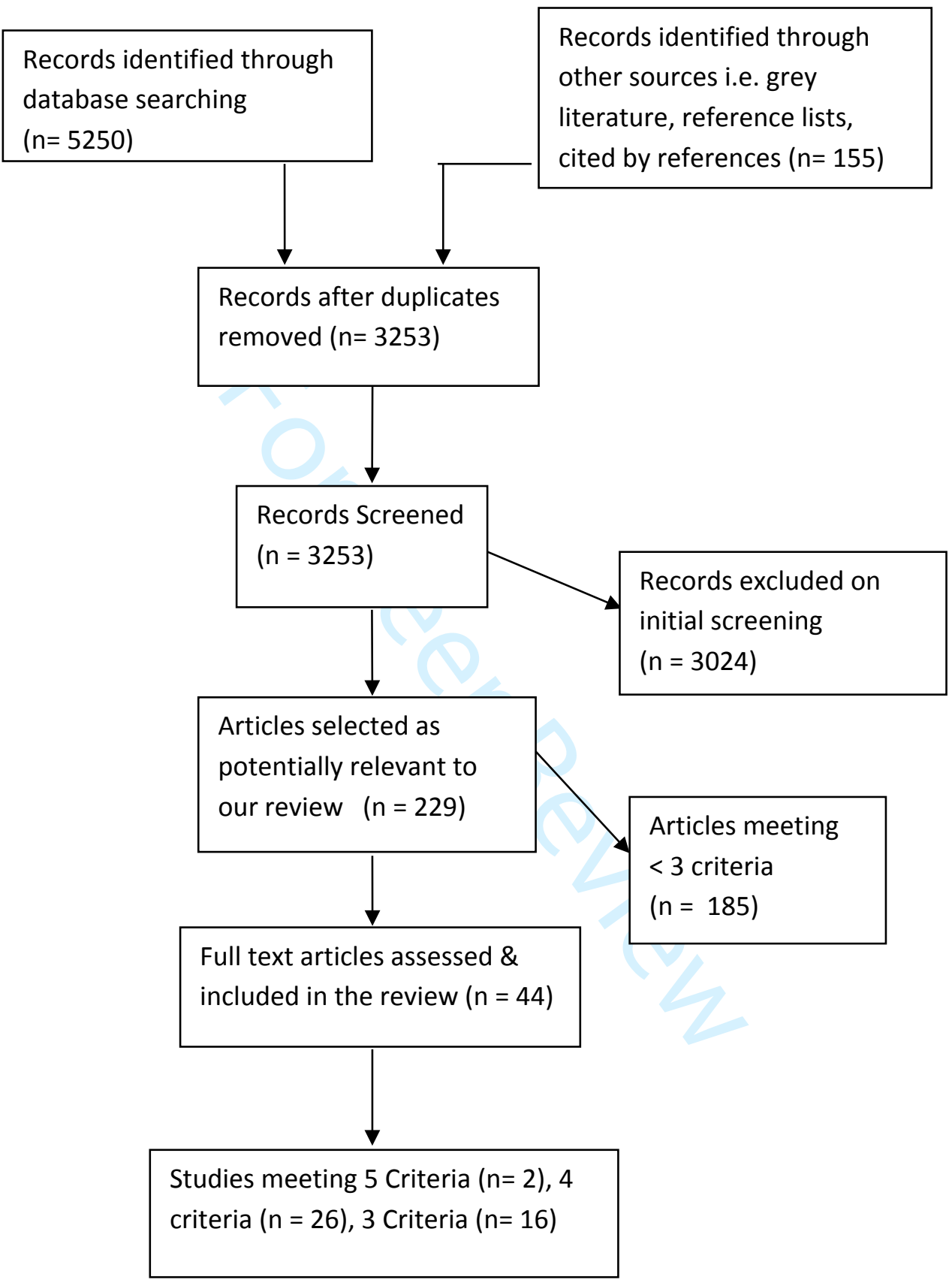




\section{Appendix 1:}

Emotionally Unstable Personality Disorder (EUPD): The diagnostic term EUPD is used throughout the article to represent both Emotionally Unstable Personality Disorder (ICD-10 F60.30 Impulsive type and F60.31 Borderline type) and Borderline Personality Disorder (DSM IV 301.83). We have retained the term EUPD throughout the article for consistency. Where the term BPD is used this is to highlight diagnostic systems used and specific terms used in the original article.

Dysrhythmia: EEG cerebral dysrhythmia denotes isolated episodic paroxysmal bursts of slow activity, controversial/anomalous spiky waveforms and/or true non-controversial epileptiform discharges

\section{Search terms -}

(“eupd” OR “borderline disorder” OR "borderline patient” OR "borderline condition” OR "borderline client" OR "borderline personality" OR "borderline personalities" OR "bpd" OR “borderline state" OR “affective instability" OR "personality disorder" OR "personality disorders" OR "PERSONALITY DISORDERS" OR "ANTISOCIAL PERSONALITY DISORDER" OR "BORDERLINE PERSONALITY DISORDER” OR “antisocial personalities" OR "antisocial personality” OR “anti-social personalities" OR "anti-social personality” OR “sociopath" OR “psychopath” OR "psychoneurotic” OR "psychoneuros*” OR “impulsivity” OR “impulse control” OR “multi-impulsivity OR multi-impulsive” OR “character disorder” OR “impulsive behaviour" OR "impulsive behavior” OR "IMPULSIVE BEHAVIOR" OR "DISRUPTIVE, IMPULSE CONTROL, AND CONDUCT DISORDERS" OR “post traumatic" OR “posttraumatic” OR “ptsd” OR "STRESS DISORDERS, POSTTRAUMATIC” OR “dyssocial” OR “socio-path”)

\section{AND}


(“AROUSAL” OR “arousal” OR “arouse" OR “aroused” OR “vigilance” OR "rest state" OR "resting state” OR "rest states" OR "resting states" OR "acute phase” OR “abnormal” OR “abnormality “ OR “abnormalities" OR “crisis" OR “crises" OR “distress" OR “distressed” OR “agitated” OR “agitation” OR "PSYCHOMOTOR AGITATION” OR “panic” OR “PANIC” OR “depressed” OR “depression” OR “depressive” OR “DEPRESSION”)

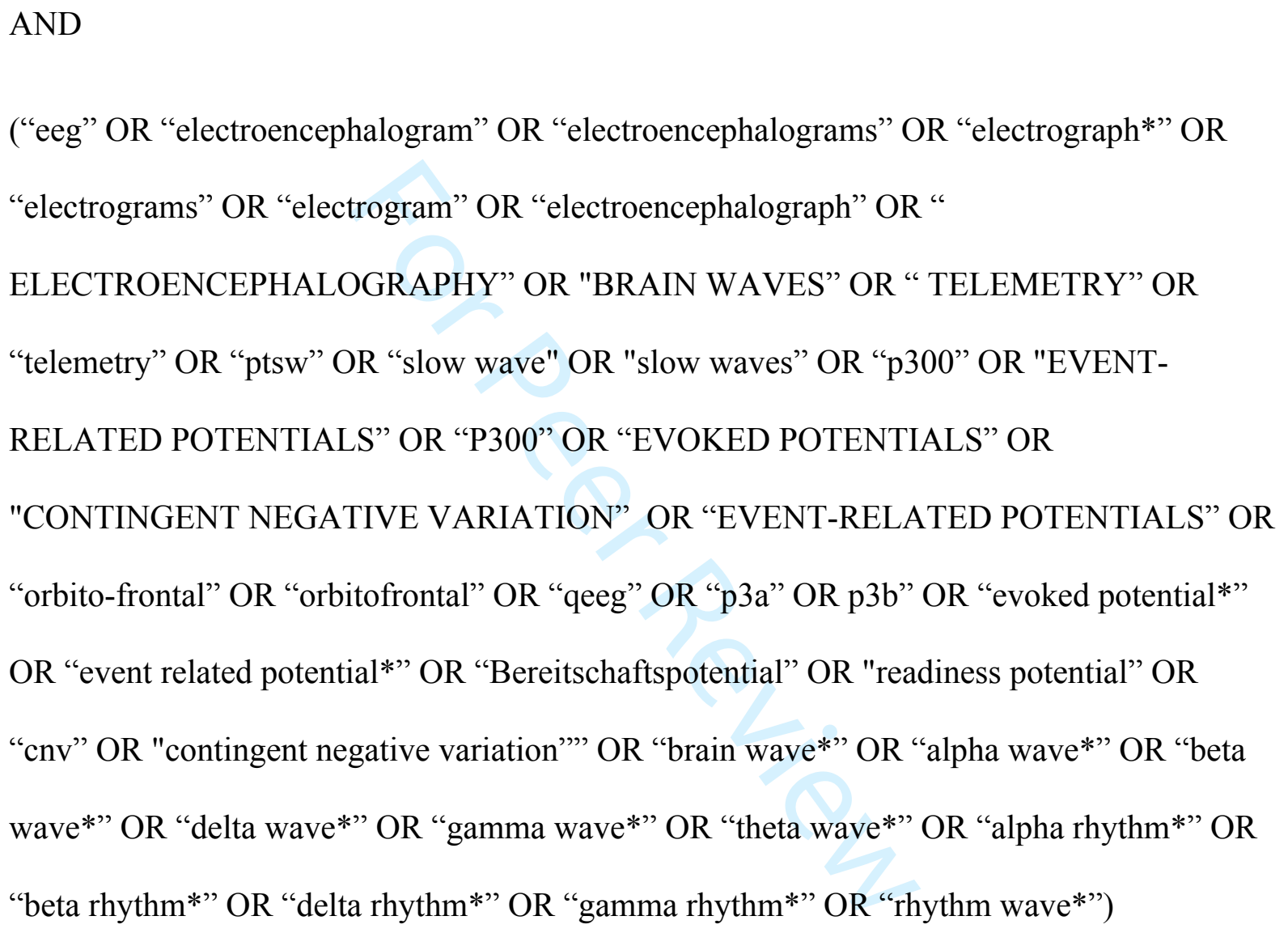




\section{Appendix 2}

\section{Search Strategy -}

1) Online database search using Medline, PsycInfo and Embase.

2) Search for grey literature.

3) Review of the references of articles meeting three or more criteria (see below)

4) Search of particularly relevant articles meeting three or more criteria for "cited by" references in Pubmed, Scopus and Google Scholar.

5) Contacting authors of relevant articles about any unpublished articles/ results.

There were no language limits in the search strategy, provided there was an English language translation of the relevant study available.

Data Sources:

Appendix 1 shows the search strategy for Medline on Healthcare Databases Advanced Search (HDAS) using a combination of text words and thesaurus terms. The same strategy was used for PsycInfo and Embase but thesaurus terms specific to the different databases were used.

Other databases were searched for grey literature using an appropriately amended strategy. The number of articles from each database is indicated in Table 12.

All articles published before the final database search in February 2018 were included.

\section{Step 1}

Any articles duplicated during the collection process were removed. Articles that were not relevant to the review were removed i.e. not relevant to electrophysiological investigation/ biological markers in personality disorder, affective disorders, general psychopathology or associated terms.

\section{Step 2}

The first and final authors applied the prearranged inclusion criteria to all abstracts. 
1) The article refers to EUPD / Borderline Personality Disorder (BPD) as the primary diagnosis

2) Must be a case-control/ cohort/ cross sectional study or higher on the hierarchy of evidence.

3) The population under investigation were all over 18 years of age

4) EEG was the only or main investigation of the study. Articles meeting criteria 4 must also refer to EUPD or equivalent terms.

5) The article refers to EEG changes during emotional fluctuations.

\section{Step 3}

Articles that met three or more of the above criteria were fully reviewed.

\section{Citation searching -}

Checks were made to ascertain whether particularly relevant articles (i.e. articles meeting three or more criteria) were cited elsewhere.

\section{Reference Lists -}

The reference list of each article screened as eligible was checked for additional articles not included through other search methods.

\section{Contact with Authors -}

Authors of articles meeting three or more criteria and included in this review were contacted to check if additional articles or any unpublished articles/ results were available. 11 authors of particularly relevant articles were contacted by email. Responses were received from four of these authors, none of whom were aware of additional unpublished studies/ results. 
Appendix 3

Preferred Reporting Items for Systematic reviews and Meta-Analyses extension for Scoping Reviews (PRISMA-ScR) Checklist

\begin{tabular}{|c|c|c|c|}
\hline SECTION & ITEM & PRISMA-ScR CHECKLIST ITEM & $\begin{array}{l}\text { REPORTED } \\
\text { ON PAGE \# }\end{array}$ \\
\hline \multicolumn{4}{|l|}{ TITLE } \\
\hline Title & 1 & Identify the report as a scoping review. & 1 \\
\hline \multicolumn{4}{|l|}{ ABSTRACT } \\
\hline $\begin{array}{l}\text { Structured } \\
\text { summary }\end{array}$ & 2 & $\begin{array}{l}\text { Provide a structured summary that includes (as } \\
\text { applicable): background, objectives, eligibility } \\
\text { criteria, sources of evidence, charting methods, } \\
\text { results, and conclusions that relate to the review } \\
\text { questions and objectives. }\end{array}$ & 2 \\
\hline \multicolumn{4}{|l|}{ INTRODUCTION } \\
\hline Rationale & 3 & $\begin{array}{l}\text { Describe the rationale for the review in the context } \\
\text { of what is already known. Explain why the review } \\
\text { questions/objectives lend themselves to a scoping } \\
\text { review approach. }\end{array}$ & 3 to 7 \\
\hline Objectives & 4 & $\begin{array}{l}\text { Provide an explicit statement of the questions and } \\
\text { objectives being addressed with reference to their } \\
\text { key elements (e.g., population or participants, } \\
\text { concepts, and context) or other relevant key } \\
\text { elements used to conceptualize the review } \\
\text { questions and/or objectives. }\end{array}$ & 7 \\
\hline \multicolumn{4}{|c|}{ 7 the } \\
\hline $\begin{array}{l}\text { Protocol and } \\
\text { registration }\end{array}$ & 5 & $\begin{array}{l}\text { Indicate whether a review protocol exists; state if } \\
\text { and where it can be accessed (e.g., a Web } \\
\text { address); and if available, provide registration } \\
\text { information, including the registration number. }\end{array}$ & NA \\
\hline Eligibility criteria & 6 & $\begin{array}{l}\text { Specify characteristics of the sources of evidence } \\
\text { used as eligibility criteria (e.g., years considered, } \\
\text { language, and publication status), and provide a } \\
\text { rationale. }\end{array}$ & $8-9$ \\
\hline $\begin{array}{l}\text { Information } \\
\text { sources* }^{*}\end{array}$ & 7 & $\begin{array}{l}\text { Describe all information sources in the search } \\
\text { (e.g., databases with dates of coverage and } \\
\text { contact with authors to identify additional sources), } \\
\text { as well as the date the most recent search was } \\
\text { executed. }\end{array}$ & Appendix 1 \\
\hline Search & 8 & $\begin{array}{l}\text { Present the full electronic search strategy for at } \\
\text { least } 1 \text { database, including any limits used, such } \\
\text { that it could be repeated. }\end{array}$ & Pathway 1 \\
\hline $\begin{array}{l}\text { Selection of } \\
\text { sources of } \\
\text { evidencet }\end{array}$ & 9 & $\begin{array}{l}\text { State the process for selecting sources of } \\
\text { evidence (i.e., screening and eligibility) included in } \\
\text { the scoping review. }\end{array}$ & $\begin{array}{l}8-9 \text { and } \\
\text { pathway } 1 \text { and } \\
\text { appendix } 1\end{array}$ \\
\hline $\begin{array}{l}\text { Data charting } \\
\text { process } \ddagger\end{array}$ & 10 & $\begin{array}{l}\text { Describe the methods of charting data from the } \\
\text { included sources of evidence (e.g., calibrated } \\
\text { forms or forms that have been tested by the team } \\
\text { before their use, and whether data charting was } \\
\text { done independently or in duplicate) and any } \\
\text { processes for obtaining and confirming data from } \\
\text { investigators. }\end{array}$ & $\begin{array}{l}8-9 \text { and } \\
\text { pathway } 1 \text { and } \\
\text { appendix } 1\end{array}$ \\
\hline Data items & 11 & $\begin{array}{l}\text { List and define all variables for which data were } \\
\text { sought and any assumptions and simplifications } \\
\text { made. }\end{array}$ & Tables 2 to 10 \\
\hline $\begin{array}{l}\text { Critical appraisal } \\
\text { of individual }\end{array}$ & 12 & $\begin{array}{l}\text { If done, provide a rationale for conducting a critical } \\
\text { appraisal of included sources of evidence; } \\
\text { describe the methods used and how this }\end{array}$ & 9 to 16 \\
\hline
\end{tabular}




\begin{tabular}{|c|c|c|c|}
\hline SECTION & ITEM & PRISMA-ScR CHECKLIST ITEM & $\begin{array}{l}\text { REPORTED } \\
\text { ON PAGE \# }\end{array}$ \\
\hline $\begin{array}{l}\text { sources of } \\
\text { evidence§ }\end{array}$ & & $\begin{array}{l}\text { information was used in any data synthesis (if } \\
\text { appropriate). }\end{array}$ & \\
\hline $\begin{array}{l}\text { Synthesis of } \\
\text { results }\end{array}$ & 13 & $\begin{array}{l}\text { Describe the methods of handling and } \\
\text { summarizing the data that were charted. }\end{array}$ & Tables 2 to 10 \\
\hline \multicolumn{4}{|l|}{ RESULTS } \\
\hline $\begin{array}{l}\text { Selection of } \\
\text { sources of } \\
\text { evidence }\end{array}$ & 14 & $\begin{array}{l}\text { Give numbers of sources of evidence screened, } \\
\text { assessed for eligibility, and included in the review, } \\
\text { with reasons for exclusions at each stage, ideally } \\
\text { using a flow diagram. }\end{array}$ & $\begin{array}{l}9 \text { to } 16 \text { and } \\
\text { tables } 2 \text { to } 10\end{array}$ \\
\hline $\begin{array}{l}\text { Characteristics of } \\
\text { sources of } \\
\text { evidence }\end{array}$ & 15 & $\begin{array}{l}\text { For each source of evidence, present } \\
\text { characteristics for which data were charted and } \\
\text { provide the citations. }\end{array}$ & 9 to 16 \\
\hline $\begin{array}{l}\text { Critical appraisal } \\
\text { within sources of } \\
\text { evidence }\end{array}$ & 16 & $\begin{array}{l}\text { If done, present data on critical appraisal of } \\
\text { included sources of evidence (see item 12). }\end{array}$ & 9 to 16 \\
\hline $\begin{array}{l}\text { Results of } \\
\text { individual sources } \\
\text { of evidence }\end{array}$ & 17 & $\begin{array}{l}\text { For each included source of evidence, present the } \\
\text { relevant data that were charted that relate to the } \\
\text { review questions and objectives. }\end{array}$ & 9 to 16 \\
\hline $\begin{array}{l}\text { Synthesis of } \\
\text { results }\end{array}$ & 18 & $\begin{array}{l}\text { Summarize and/or present the charting results as } \\
\text { they relate to the review questions and objectives. }\end{array}$ & $\begin{array}{l}9 \text { to } 16 \text { and } \\
\text { tables } 2 \text { to } 10\end{array}$ \\
\hline \multicolumn{4}{|l|}{ DISCUSSION } \\
\hline $\begin{array}{l}\text { Summary of } \\
\text { evidence }\end{array}$ & 19 & $\begin{array}{l}\text { Summarize the main results (including an } \\
\text { overview of concepts, themes, and types of } \\
\text { evidence available), link to the review questions } \\
\text { and objectives, and consider the relevance to key } \\
\text { groups. }\end{array}$ & $16-18$ \\
\hline Limitations & 20 & $\begin{array}{l}\text { Discuss the limitations of the scoping review } \\
\text { process. }\end{array}$ & $16-18$ \\
\hline Conclusions & 21 & $\begin{array}{l}\text { Provide a general interpretation of the results with } \\
\text { respect to the review questions and objectives, as } \\
\text { well as potential implications and/or next steps. }\end{array}$ & 19 \\
\hline \multicolumn{4}{|l|}{ FUNDING } \\
\hline Funding & 22 & $\begin{array}{l}\text { Describe sources of funding for the included } \\
\text { sources of evidence, as well as sources of funding } \\
\text { for the scoping review. Describe the role of the } \\
\text { funders of the scoping review. }\end{array}$ & NA \\
\hline
\end{tabular}

$\mathrm{JBI}=$ Joanna Briggs Institute; PRISMA-ScR = Preferred Reporting Items for Systematic reviews and MetaAnalyses extension for Scoping Reviews.

* Where sources of evidence (see second footnote) are compiled from, such as bibliographic databases, social media platforms, and Web sites.

† A more inclusive/heterogeneous term used to account for the different types of evidence or data sources (e.g., quantitative and/or qualitative research, expert opinion, and policy documents) that may be eligible in a scoping review as opposed to only studies. This is not to be confused with information sources (see first footnote). ‡ The frameworks by Arksey and O'Malley (6) and Levac and colleagues $(7)$ and the JBI guidance $(4,5)$ refer to the process of data extraction in a scoping review as data charting.

$\S$ The process of systematically examining research evidence to assess its validity, results, and relevance before using it to inform a decision. This term is used for items 12 and 19 instead of "risk of bias" (which is more applicable to systematic reviews of interventions) to include and acknowledge the various sources of evidence that may be used in a scoping review (e.g., quantitative and/or qualitative research, expert opinion, and policy document).

From: Tricco AC, Lillie E, Zarin W, O'Brien KK, Colquhoun H, Levac D, et al. PRISMA Extension for Scoping Reviews (PRISMA-ScR): Checklist and Explanation. Ann Intern Med. ;169:467-473. doi: 10.7326/M18-0850 


\section{Appendix 4:}

\section{EUPD and EEG: Checklist and Questions for EEG Findings.}

\section{Questions For Findings in QEEG/ Digital EEG.}

(Examine the Z-score tables for the distribution of abnormalities)

1) Does the QEEG/Digital EEG show presence of Interhemispheric and Intrahemispheric Coherence.

(a) Greater left cortical activation (EUPD).

(b) Greater right cortical activation (Major Depression).

(c) Significant delay in early posterior gamma* synchrony \& reduced right hemisphere late gamma synchrony.

(d) Delay in posterior gamma synchrony associated with cognitive symptoms

(e) Reduced right hemisphere gamma synchrony associated with impulsivity

*gamma - (37-41 Hz)

2) What is the Absolute Power in

(a) delta $(<3 \mathrm{~Hz})$

(b) theta* $(4-7 \mathrm{~Hz})$

(c) alpha $(8-12 \mathrm{~Hz})$

(d) beta $(>13 \mathrm{~Hz})$

* Total theta power higher in EUPD.

3) What is the Relative Power in
(a) delta
(b) theta
(c) alpha

(i) Less stable EEG-vigilance pattern ' $A$ ' with a tendency to drop to lower vigilance states ' $B$ ' (' $A^{\prime}=$ at least one EEG channel shows a relative alpha power $>50 \%$ compared to the total power of the respective channel. 
'B'=No clear alpha rhythm in any channels)

(d) beta

4) What is the Mean Frequency.

(a) Does the mean frequency on spectral analysis correlate with anxiety levels.

5) Presence of Asymmetry Values

\section{Questions for Findings in Standard EEG.}

Does the EEG indicate the following?

6) Diffuse slowing

7) Dysrhythmias (EEG cerebral dysrhythmia denotes isolated episodic paroxysmal bursts of slow activity, suppression of waveforms, controversial/anomalous spiky waveforms, sharp waves and/or true non-controversial epileptiform discharges).

8) Sharp waves, especially in posterior areas

9) Increased slow wave activity

10)

(a) Increased prevalence of intermittent rhythmic delta (IRDA) or theta (IRTA) activity.

(b) random or semi-rhythmic theta and/or delta

11) Abnormalities in Temporal lobe areas.

12) Epileptiform patterns

\section{Questions for Findings in Sleep EEG.}

Does the EEG indicate the following?

13) Increased REM percentage

14) Increased REM density

15) Shorter REM latency (much shorter in EUPD with Depression)

16) Longer REM period.

17) Increased delta power in Non-REM sleep. 
18) Reduced slow wave, stage $3 \& 4$ sleep

\section{Questions for Findings in Evoked Potentials.}

Does the EEG indicate the following?

19) Increased P300 latency

20) Decreased P300 amplitude

21) Increased amplitude of P3a and loss of temporal synchronicity of P3a with P3b.

22) Larger late positive potentials (LPP).

23) Higher loudness dependence of the N1/P2 component of auditory evoked potentials.

24) Reduced P3 amplitudes during No-go responses in Go-No-go test.

25) Smaller LPC amplitude

26) Increase in slow wave frequencies (theta, delta and slow alpha) in the orbital cortex, dorsomedial prefrontal or dorsolateral prefrontal cortexes

27) Decreased P300 latency 


\section{Appendix 5}

Generating the Checklist based on Findings in relevant articles.

Q1-Q25 indicate the question generated based on the individual article findings.

\begin{tabular}{|c|c|c|}
\hline Articles & Findings & Finding based Questions: \\
\hline $\begin{array}{l}\text { Beeney et. al. } \\
2014 \text { (38) }\end{array}$ & $\begin{array}{l}\text { EUPD - greater left cortical } \\
\text { activation, MDD - greater right } \\
\text { cortical activation. } \\
\text { Q1 }\end{array}$ & $\begin{array}{l}\text { Questions for Findings in QEEG/ Digital EEG. } \\
\text { (Examine the Z-score tables for the distribution of }\end{array}$ \\
\hline $\begin{array}{l}\text { Russ et. al. } 1999 \\
\text { (39) }\end{array}$ & $\begin{array}{l}\text { Total theta power significantly } \\
\text { higher. } \\
\text { Q2 }\end{array}$ & $\begin{array}{l}\text { abnormalities) } \\
\text { 1. Does the QEEG/Digital EEG show presence of } \\
\text { Interhemispheric and Intrahemispheric Coherence. } \\
\text { (a) Greater left cortical activation (EUPD). } \\
\text { (b) Greater right cortical activation (Major } \\
\text { Depression). } \\
\text { (c) Significant delay in early posterior gamma* } \\
\text { synchrony \& reduced right hemisphere late } \\
\text { gamma synchrony. } \\
\text { (d) delay in posterior gamma synchrony associated } \\
\text { with cognitive symptoms } \\
\text { (e) Reduced right hemisphere gamma synchrony } \\
\text { associated with impulsivity } \\
\text { *gamma - ( } 37-41 \mathrm{~Hz} \text { ) } \\
\text { 2. What is the Absolute Power in } \\
\text { (a) delta (<3Hz) } \\
\text { (b) theta* ( } 4-7 \mathrm{~Hz} \text { ) } \\
\text { (c) alpha ( } 8-12 \mathrm{~Hz} \text { ) } \\
\text { (d) beta ( }>13 \mathrm{~Hz} \text { ) } \\
\text { * Total theta power higher in EUPD. }\end{array}$ \\
\hline
\end{tabular}




\begin{tabular}{|c|c|c|}
\hline & & $\begin{array}{l}\text { 3. What is the Relative Power in } \\
\text { (a) delta } \\
\text { (b) theta } \\
\text { (c) alpha } \\
\text { (i) Less stable EEG-vigilance pattern 'A' with a } \\
\text { tendency to drop to lower vigilance states 'B' } \\
\text { ('A'= at least one EEG channel shows a relative } \\
\text { alpha power }>50 \% \text { compared to the total power of } \\
\text { the respective channel. } \\
\text { 'B'=No clear alpha rhythm in any channels) } \\
\text { (d) beta } \\
4 . \text { What is the Mean Frequency. } \\
\text { (a) Does the mean frequency on spectral analysis } \\
\text { correlate with anxiety levels. } \\
\text { (a) }\end{array}$ \\
\hline $\begin{array}{l}\text { Ogiso et al. } 1993 \\
\text { (41) }\end{array}$ & NONE & $\begin{array}{l}\text { Questions for Findings in Standard EEG. } \\
\text { Does the EEG indicate the following? } \\
\text { 6. Diffuse slowing }\end{array}$ \\
\hline $\begin{array}{l}\text { De La Fuente, } \\
1998(42)\end{array}$ & $\begin{array}{l}\text { EUPD -diffuse slowing on EEG } \\
\text { Q6 }\end{array}$ & $\begin{array}{l}\text { 7. Dysrhythmias (EEG cerebral dysrhythmia } \\
\text { denotes isolated episodic paroxysmal bursts of } \\
\text { slow activity, suppression of waveforms, }\end{array}$ \\
\hline $\begin{array}{l}\text { Cornelius et al. } \\
1986(43)\end{array}$ & $\begin{array}{l}\text { EUPD - EEG dysrhythmias } \\
\text { Q7 }\end{array}$ & $\begin{array}{l}\text { controversial/anomalous spiky waveforms, sharp } \\
\text { waves and/or true non-controversial epileptiform } \\
\text { discharges). }\end{array}$ \\
\hline $\begin{array}{l}\text { Cowdry et al. } 1986 \\
\text { (44) }\end{array}$ & $\begin{array}{l}\text { EUPD - posterior sharp waves } \\
\text { Q8 }\end{array}$ & $\begin{array}{l}\text { 8. Sharp waves, especially in posterior areas } \\
\text { 9. Increased slow wave activity } \\
\text { 10. }\end{array}$ \\
\hline $\begin{array}{l}\text { Synder \& Pitts, } \\
1984(45)\end{array}$ & $\begin{array}{l}\text { EUPD -Increased slow wave } \\
\text { activity } \\
\text { Q9 }\end{array}$ & $\begin{array}{l}\text { (a) Increased prevalence of intermittent rhythmic } \\
\text { delta (IRDA) or theta (IRTA) activity. } \\
\text { (b) random or semi-rhythmic theta and/or delta }\end{array}$ \\
\hline $\begin{array}{l}\text { Hegerl et al. } \\
2008(46)\end{array}$ & $\begin{array}{l}\text { EUPD - less stable EEG-vigilance } \\
\text { pattern with a tendency to drop } \\
\text { to lower vigilance states } \\
(p=0.03) \text {. Q3ci }\end{array}$ & $\begin{array}{l}\text { 11. CNS abnormalities focal to Temporal lobe } \\
\text { areas. } \\
\text { 12. Epileptiform patterns }\end{array}$ \\
\hline Van Elst, 2016 (47) & $\begin{array}{l}\text { EUPD - significantly increased } \\
\text { prevalence of IRDAs and IRTAs } \\
\text { (intermittent rhythmic delta or } \\
\text { theta activity) }\end{array}$ & \\
\hline
\end{tabular}




\begin{tabular}{|c|c|c|}
\hline & Q10a & \multirow{12}{*}{$\begin{array}{l}\text { Questions for Findings in Sleep EEG. } \\
\text { Does the EEG indicate the following? } \\
\text { 13. Increased REM percentage } \\
\text { 14. Increased REM density } \\
\text { 15. Shorter REM latency (much shorter in EUPD } \\
\text { with Depression) } \\
\text { 16. Longer REM period. } \\
\text { 17. Increased delta power in Non-REM sleep. } \\
\text { 18. Reduced slow wave, stage } 3 \& 4 \text { sleep }\end{array}$} \\
\hline $\begin{array}{l}\text { Yerevanian et al. } \\
1985(48)\end{array}$ & $\begin{array}{l}\text { EUPD - EEG abnormalities, most } \\
\text { commonly in temporal lobe } \\
\text { areas (abnormalities not } \\
\text { discussed in detail) } \\
\text { Q11,12 }\end{array}$ & \\
\hline $\begin{array}{l}\text { Assad et. al. } 2002 \\
\text { (49) }\end{array}$ & $\begin{array}{l}\text { EUPD - REM \% \& REM density } \\
\text { higher, REM latency shorter, } \\
\text { longer REM period. (Changes } \\
\text { less robust than in those with } \\
\text { depression) } \\
\text { Q13, Q14, Q15, } 16\end{array}$ & \\
\hline $\begin{array}{l}\text { Philipsen et. al. } \\
2005 \text { (50) }\end{array}$ & $\begin{array}{l}\text { EUPD - Higher delta power in } \\
\text { NonREM sleep. } \\
\text { Q17 }\end{array}$ & \\
\hline $\begin{array}{l}\text { De La Fuente, } \\
2004 \text { (51) }\end{array}$ & $\begin{array}{l}\text { EUPD -significantly less stage } 3 \\
\text { sleep and slow wave sleep and } \\
\text { a longer duration of REM sleep. } \\
\text { Q18 }\end{array}$ & \\
\hline $\begin{array}{l}\text { De La Fuente, } \\
2001(52)\end{array}$ & $\begin{array}{l}\text { EUPD - longer duration of REM } \\
\text { sleep, significantly less stage 3, } \\
\text { stage } 4 \text { and slow wave sleep. } \\
\text { Q16, Q18 }\end{array}$ & \\
\hline $\begin{array}{l}\text { Battaglia et al. } \\
1993(53)\end{array}$ & $\begin{array}{l}\text { EUPD - Reduced REM latency. } \\
\text { Q15 }\end{array}$ & \\
\hline $\begin{array}{l}\text { Battaglia et al. } \\
1999(54)\end{array}$ & $\begin{array}{l}\text { EUPD - Increased REM density } \\
\text { in first REM cycle. } \\
\text { Q14 }\end{array}$ & \\
\hline $\begin{array}{l}\text { Bell et al. } 1983 \\
\text { (55) }\end{array}$ & $\begin{array}{l}\text { EUPD patients with depression } \\
\text { had shorter REM latencies than } \\
\text { non-depressed EUPD patients. } \\
\text { Reduced REM latency both } \\
\text { groups } \\
\text { Q15 }\end{array}$ & \\
\hline $\begin{array}{l}\text { Mcnamara et al. } \\
1984 \text { (56) }\end{array}$ & $\begin{array}{l}\text { EUPD and depressive groups } \\
\text { both had Shorter REM latency } \\
\text { and increased REM density. } \\
\text { Q14, Q15 }\end{array}$ & \\
\hline $\begin{array}{l}\text { Akiskal et al. } 1985 \\
\text { (57) }\end{array}$ & $\begin{array}{l}\text { EUPD - Shorter REM latency } \\
\text { than healthy controls and non- } \\
\text { EUPD personality disorder } \\
\text { patients, but similar results to } \\
\text { those with affective disorders } \\
\text { Q15 }\end{array}$ & \\
\hline $\begin{array}{l}\text { Reynolds et al. } \\
1985 \text { (58) }\end{array}$ & $\begin{array}{l}\text { EUPD - Reduced REM latency, } \\
\text { but similar to those with } \\
\text { depression } \\
\text { Q15 }\end{array}$ & \\
\hline
\end{tabular}




\begin{tabular}{|c|c|c|}
\hline $\begin{array}{l}\text { Blackwood et al. } \\
1986\end{array}$ & $\begin{array}{l}\text { EUPD - Longer P300 latency and } \\
\text { smaller amplitude. } \\
\text { Q19, Q20 }\end{array}$ & \multirow{10}{*}{$\begin{array}{l}\text { Questions for Findings in Evoked Potentials. } \\
\text { Does the EEG indicate the following? } \\
\text { 19. Increased P300 latency } \\
\text { 20. Decreased P300 amplitude } \\
\text { 21. Increased amplitude of P3a and loss of } \\
\text { temporal synchronicity of P3a with P3b. } \\
\text { 22. Larger late positive potentials (LPP). } \\
\text { 23. Higher loudness dependence of the N1/P2 } \\
\text { component of auditory evoked potentials. } \\
\text { 24. Reduced P3 amplitudes during Nogo responses } \\
\text { in Go-Nogo test. } \\
\text { 25. Smaller LPC amplitude }\end{array}$} \\
\hline Kutcher et al. 1987 & $\begin{array}{l}\text { EUPD - Longer P300 latency and } \\
\text { decreased P300 amplitude. } \\
\text { Q19, Q20 }\end{array}$ & \\
\hline Kutcher et al. 1989 & $\begin{array}{l}\text { EUPD (BPD) - Prolonged P300 } \\
\text { latency and decreased P300 } \\
\text { amplitude. } \\
\text { Q19, Q20 }\end{array}$ & \\
\hline Drake et al. 1991 & $\begin{array}{l}\text { EUPD (BPD) Prolonged P300 } \\
\text { latency and decreased P300 } \\
\text { amplitude. } \\
\text { Q19, Q20 }\end{array}$ & \\
\hline Meares et al. 2004 & $\begin{array}{l}\text { EUPD (BPD) - Enhanced } \\
\text { amplitude of P3a and loss of } \\
\text { temporal synchronicity of P3a } \\
\text { with P3b. Natural age-related } \\
\text { decline in P3a amplitude } \\
\text { reduced in BPD. } \\
\text { Q21 }\end{array}$ & \\
\hline $\begin{array}{l}\text { Marissen et al. } \\
2010\end{array}$ & $\begin{array}{l}\text { EUPD (BPD) - Larger LPP (late } \\
\text { positive potentials) to pictures } \\
\text { with an unpleasant valence. } \\
\text { Q22 }\end{array}$ & \\
\hline He et al, 2012 & NONE & \\
\hline $\begin{array}{l}\text { Archer et al. } 1988 \\
(66)\end{array}$ & NONE & \\
\hline $\begin{array}{l}\text { Houston et al. } \\
2005 \text { (67) }\end{array}$ & NONE & \\
\hline $\begin{array}{l}\text { Houston et al. } \\
2004 \text { (68) }\end{array}$ & $\begin{array}{l}\text { EUPD - Reduced P300 } \\
\text { amplitude. } \\
\text { Q20 }\end{array}$ & \\
\hline $\begin{array}{l}\text { Schaaff et al. } 2007 \\
\text { (69) }\end{array}$ & $\begin{array}{l}\text { EUPD - Significantly higher } \\
\text { loudness dependence of the } \\
\text { N1/P2 component of auditory } \\
\text { evoked potentials. Q } 23\end{array}$ & \\
\hline $\begin{array}{l}\text { Cornelius et al. } \\
1988(70)\end{array}$ & $\begin{array}{l}\text { EUPD - Mean frequency on } \\
\text { spectral analysis correlated with } \\
\text { anxiety levels. Q4 }\end{array}$ & \\
\hline $\begin{array}{l}\text { De La Fuente et al. } \\
2011 \text { (71) }\end{array}$ & $\begin{array}{l}\text { TSH and standard EEG results } \\
\text { influence sleep EEG, neurologic } \\
\text { soft signs and post } \\
\text { dexamethasone cortisol in } \\
\text { patients with EUPD. Q6, Q10b }\end{array}$ & \\
\hline
\end{tabular}




\begin{tabular}{|c|c|c|}
\hline $\begin{array}{l}\text { Ruchsow et al. } \\
2008 \text { (72) }\end{array}$ & $\begin{array}{l}\text { EUPD - reduced P3 amplitudes } \\
\text { during Nogo responses in Go- } \\
\text { Nogo test. } \\
\text { Q24 }\end{array}$ & \\
\hline $\begin{array}{l}\text { Vega et al. } 2017 \\
\text { (73) }\end{array}$ & fMRI study, EEG not used/done & No EEG findings \\
\hline $\begin{array}{l}\text { Williams et al. } \\
2006 \text { (74) }\end{array}$ & $\begin{array}{l}\text { EUPD - significant delay in early } \\
\text { posterior gamma synchrony \& } \\
\text { reduced right hemisphere late } \\
\text { gamma synchrony. Delay in } \\
\text { posterior synchrony was } \\
\text { associated with cognitive } \\
\text { symptoms and reduced right } \\
\text { hemisphere synchrony was } \\
\text { associated with impulsivity. } \\
\text { Q1c, Q1d, Q1e. }\end{array}$ & \\
\hline $\begin{array}{l}\text { Cohen et al. } 2016 \\
\text { (75) }\end{array}$ & $\begin{array}{l}\text { EUPD - Mild to moderate } \\
\text { increase in slow wave } \\
\text { frequencies (theta, delta and } \\
\text { slow alpha) in the orbital cortex, } \\
\text { dorsomedial prefrontal and } \\
\text { dorsolateral prefrontal } \\
\text { cortexes. } \\
\text { Q26 }\end{array}$ & $\begin{array}{l}\text { 26. Increase in slow wave frequencies (theta, delta } \\
\text { and slow alpha) in the orbital cortex, dorsomedial } \\
\text { prefrontal or dorsolateral prefrontal cortexes } \\
\text { (Compare with question } 9 \& 18 \text { ) }\end{array}$ \\
\hline $\begin{array}{l}\text { Brazier et al. } 1945 \\
\text { (76) }\end{array}$ & $\begin{array}{l}\text { Higher incidence of beta activity } \\
\text { in psychoneurosis versus } \\
\text { controls (critical ratio } 6.54 \text { ). } \\
\text { No established EUPD diagnosis. }\end{array}$ & No relevant findings \\
\hline Hill et al. 2005 (77) & $\begin{array}{l}\text { EUPD traits - had smaller LPC } \\
\text { amplitude, decreased P300 } \\
\text { latency, and decreased P300 } \\
\text { amplitudes when making } \\
\text { incorrect responses to } \\
\text { emotional pictures and faces. } \\
\text { Q20, Q25, Q27 }\end{array}$ & 27. Decreased P300 latency \\
\hline $\begin{array}{l}\text { Shaofang Xu et al. } \\
2014 \text { (78) }\end{array}$ & $\begin{array}{l}\text { TRD \& GAD - Reduced P3 } \\
\text { amplitude in those with TRD \& } \\
\text { GAD compared to healthy } \\
\text { controls and those with EUPD. } \\
\text { EUPD used as control group. }\end{array}$ & No relevant findings \\
\hline $\begin{array}{l}\text { Teicher et al. } 1997 \\
\text { (29) }\end{array}$ & No established EUPD diagnosis & No relevant findings \\
\hline $\begin{array}{l}\text { Shen et al. } 2008 \\
\text { (79) }\end{array}$ & NONE & No significant findings \\
\hline $\begin{array}{l}\text { Huang-Storms et } \\
\text { al. } 2006 \text { (37) }\end{array}$ & No established diagnosis & No relevant findings \\
\hline
\end{tabular}


Table 1. Articles on the relationship between EEG changes and psychopathology

Paper

Shelley et al, 2009.7

Abrams et al, $1980 .^{8}$

Schoenberg et al, $2014 .^{9}$

Small et al, $1984 .^{10}$

Gallinat et al, 2016. ${ }^{11}$
Type of article

Findings
Review article

Cross-sectional study

Review article

Cohort study

Review article

\author{
Higher incidence of EEG abnormalities in \\ the nonepileptic neuropsychiatric \\ population than the normal population in \\ 25 out of 29 articles reviewed
}

Significant correlations between left-sided EEG abnormality and formal thoughtdisorder and emotional blunting (sample size: 159 patients with schizophrenia/ affective disorder)

$-81 \%$ of 63 articles reviewed reported clinical amelioration related to biofeedback, $65 \%$ to a statistically significant level $(p<0.05)$

-EEG neurofeedback was the most investigated modality of biofeedback

-Anxiety disorders were the most commonly treated with biofeedback

-Multi-modal biofeedback appeared most effective in significantly ameliorating symptoms

EEG abnormalities predicted diagnostic change (33\% rediagnosed with affective, organic or other disorders) \& relatively favourable prognosis in a sample of 759 hospitalised patients with schizophrenia

-Specific EEG changes in Alzheimers disease (increase in delta and theta activity, decrease in beta activity, slowing of the alpha basal rhythm and reduction of the topographical structure) (7 articles on Alzheimers disease reviewed)

-EEG changes in delirium (slowing of delta and theta activity) ( 2 articles on delirium 
McLoughlin et al, 2013. ${ }^{12}$

Review article

Balogh et al, 2010. ${ }^{13}$

Hughes et al, 1999. ${ }^{14}$
Review article

Review article reviewed)

- EEG changes specific to Lithium intoxication ( 7 articles), Clozapine (3 articles) and Benzodiazepines (1 article)

-EEG has improved understanding of face processing ( 3 articles), cognitive control ( 2 articles) and mirror neuron activity (1 article) in the general population.

- Independent component analysis of EEG can identify brain sources that correspond to distinct suggested emotions ( 1 article)

-Patients with a diagnosis of schizophrenia, anorexia nervosa or EUPD exhibited a decrease in amplitude \& those with depression and anxiety an increase in amplitude of error-negativity (an evoked potential component) (number of studies reviewed not recorded)

-EEG and Quantitative EEG changes can be seen in anxiety disorder (7 articles), depression (27 articles), dementia (62 articles), obsessive-compulsive disorder (7 articles), schizophrenia (52 articles) \& intellectual disabilities or attention deficit disorder (20 articles) 
Table 2. Articles which met all 5 Criteria

\begin{tabular}{|c|c|c|c|c|c|c|c|}
\hline Article & $\begin{array}{l}\text { Diagnosti } \\
\text { c System }\end{array}$ & $\begin{array}{l}\text { N (male } \\
\text { /female } \\
\text { ) }\end{array}$ & $\begin{array}{l}\text { Medication } \\
\text { s }\end{array}$ & $\begin{array}{l}\text { Comorbid } \\
\text { conditions }\end{array}$ & $\begin{array}{l}\text { Control } \\
\text { group }\end{array}$ & Findings & $\begin{array}{l}\text { Study } \\
\text { Design/EE } \\
\text { G type/ } \\
\text { Statistical } \\
\text { Test used }\end{array}$ \\
\hline
\end{tabular}

\begin{tabular}{|c|c|c|c|c|c|c|c|}
\hline $\begin{array}{l}\text { Beeney } \\
\text { et. al. } \\
2014 .{ }^{49}\end{array}$ & $\begin{array}{l}\text { IPDE }^{97} \\
\text { and LEAD } \\
\text { standard, } \\
98,99 \\
\text { SCID-1, }{ }^{100}\end{array}$ & $\begin{array}{l}23 \\
(0 / 23)\end{array}$ & $\begin{array}{l}\text { Not } \\
\text { discussed }\end{array}$ & $\begin{array}{l}\text { No } \\
\text { depressive } \\
\text { episode in } \\
\text { last } 6 \\
\text { months. } \\
\text { Psychotic } \\
\text { disorders, } \\
\text { Bipolar } 1\end{array}$ & $\begin{array}{l}\text { Major } \\
\text { depressive } \\
\text { disorder } \\
\text { (MDD) } \\
\text { Healthy } \\
\text { controls } \\
\text { (HC) }\end{array}$ & $\begin{array}{l}\text { Following } \\
\text { rejection, } \\
\text { individual } \\
\text { s with } \\
\text { EUPD } \\
\text { showed } \\
\text { greater } \\
\text { left } \\
\text { cortical } \\
\text { activation } \\
\text {, those } \\
\text { with MDD } \\
\text { greater } \\
\text { right } \\
\text { cortical } \\
\text { activation } \\
\text { and HCs a } \\
\text { more } \\
\text { balanced } \\
\text { cortical } \\
\text { profile } \\
\text { (p<0.001). }\end{array}$ & $\begin{array}{l}\text { Case- } \\
\text { control } \\
\text { Study. } \\
\text { Scalp EEG } \\
\text { using128- } \\
\text { channel } \\
\text { geodesic } \\
\text { sensor net. } \\
\text { Electrode } \\
\text { placement } \\
\text { not } \\
\text { specified. } \\
\text { Artifacts } \\
\text { removed } \\
\text { using } \\
\text { independe } \\
\text { nt } \\
\text { component } \\
\text { analysis. } \\
\text { ANOVA and } \\
\text { Tukey's } \\
\text { HSD post } \\
\text { hoc tests }\end{array}$ \\
\hline $\begin{array}{l}\text { Russ et. } \\
\text { al. } \\
1999 .^{50}\end{array}$ & SCID-II, ${ }^{101}$ & $\begin{array}{l}41 \\
(0 / 41)\end{array}$ & $\begin{array}{l}\text { Antidepres } \\
\text { sants, } \\
\text { antipsychot } \\
\text { ics, mood } \\
\text { stabilizers, } \\
\text { benzodiaze } \\
\text { pines }\end{array}$ & $\begin{array}{l}\text { High rate of } \\
\text { Axis I and II } \\
\text { co- } \\
\text { morbidities }\end{array}$ & $\begin{array}{l}\text { Major } \\
\text { depression } \\
\text { Healthy } \\
\text { controls }\end{array}$ & $\begin{array}{l}\text { Total } \\
\text { theta } \\
\text { power } \\
\text { significant } \\
\text { ly higher } \\
\text { in EUPD- } \\
\text { NP than } \\
\text { depressiv } \\
\text { e group } \\
\text { ( } p=0 .\end{array}$ & $\begin{array}{l}\text { Cohort } \\
\text { Study. } 16 \\
\text { channel } \\
\text { scalp EEGs } \\
\text { using } 10-20 \\
\text { system. } \\
\text { Artifacts } \\
\text { removed } \\
\text { following } \\
\text { manual }\end{array}$ \\
\hline
\end{tabular}




$\begin{array}{ll}\begin{array}{l}\text { O074) and } \\ \text { healthy } \\ \text { controls }\end{array} & \text { review. } \\ (\mathrm{p}<0.0001 & \text { were log } \\ ) . & \begin{array}{l}\text { transforme } \\ \mathrm{d} \text { to }\end{array} \\ \text { Total } & \text { approximat } \\ \text { theta } & \mathrm{e} \\ \text { power } & \text { normality. } \\ \text { was } & \text { Following } \\ \text { significant } & \text { this, } \\ \text { ly higher } & \text { repeated } \\ \text { in the } & \text { measures } \\ \text { EUPD-P } & \text { ANCOVAs } \\ \text { group } & \text { were used. } \\ \text { compared } & \\ \text { to normal } & \\ \text { controls } & \\ \text { ( } p=0.016) & \end{array}$

Tukeys HSD = Tukey's honestly significant difference test, EUPD-P/ EUPD-NP = patients with EUPD who are sensitive/ not sensitive to pain following self-injurious activity.

Table 3. Articles using Standard EEGs

\begin{tabular}{|c|c|c|c|c|c|c|c|}
\hline Article & $\begin{array}{l}\text { Diagnosti } \\
\text { c System }\end{array}$ & $\begin{array}{l}\text { N (male } \\
\text { /female } \\
\text { ) }\end{array}$ & $\begin{array}{l}\text { Medication } \\
\text { s }\end{array}$ & $\begin{array}{l}\text { Comorbid } \\
\text { condition } \\
\text { s }\end{array}$ & $\begin{array}{l}\text { Control } \\
\text { group }\end{array}$ & Findings & $\begin{array}{l}\text { Study } \\
\text { Design/EEG } \\
\text { type/ } \\
\text { Statistical } \\
\text { test used }\end{array}$ \\
\hline $\begin{array}{l}\text { Ogiso } \\
\text { et al. } \\
1993.5 \\
2\end{array}$ & $\begin{array}{l}\text { DIB }^{102}>7 \\
\& \text { DSM- } \\
\text { III. }^{103}\end{array}$ & $\begin{array}{l}18 \\
(0 / 18)\end{array}$ & $\begin{array}{l}\text { Anxiolytics, } \\
\text { antipsychot } \\
\text { ics, } \\
\text { antidepress } \\
\text { ants }\end{array}$ & $\begin{array}{l}\text { Affective } \\
\text { disorders, } \\
\text { eating } \\
\text { disorders } \\
\text { and } \\
\text { substance } \\
\text { abuse }\end{array}$ & $\begin{array}{l}\text { Non-EUPD } \\
\text { in-patients } \\
\text { (DIB }<7 \text { and } \\
\text { without } \\
\text { DSM-III } \\
\text { diagnosis } \\
\text { of BPD). }\end{array}$ & $\begin{array}{l}\text { No } \\
\text { characteri } \\
\text { stic EEG } \\
\text { changes } \\
\text { in EUPD } \\
\text { vs. } \\
\text { control } \\
\text { group. } \\
\text { Positive }\end{array}$ & $\begin{array}{l}\text { Case control } \\
\text { study. EEGs } \\
\text { recorded } \\
\text { using 10-20 } \\
\text { technique } \\
\text { through } \\
\text { monopolar \& } \\
\text { bipolar } \\
\text { leads. }\end{array}$ \\
\hline
\end{tabular}




\begin{tabular}{|c|c|c|c|c|c|c|c|}
\hline & & & & & & $\begin{array}{l}\text { spikes } \\
\text { appeared } \\
\text { in } \\
\text { patients } \\
\text { with high } \\
\text { scores for } \\
\text { impulse } \\
\text { action } \\
\text { patterns } \\
\text { on DIB. }\end{array}$ & $\begin{array}{l}\text { Mean values } \\
\text { of frequency } \\
\text { and } \\
\text { amplitude } \\
\text { were } \\
\text { analysed by } \\
\text { the T-test. } \\
\text { Fishers exact } \\
\text { test was } \\
\text { used for } \\
\text { other } \\
\text { statistical } \\
\text { comparisons. }\end{array}$ \\
\hline $\begin{array}{l}\text { De La } \\
\text { Fuent } \\
\text { e, } \\
1998^{53}\end{array}$ & $\begin{array}{l}\text { DSM-III- } \\
\text { R, }^{104} \& \\
\text { DIB. }^{102}\end{array}$ & $\begin{array}{l}20 \\
(6 / 14)\end{array}$ & $\begin{array}{l}\text { None for at } \\
\text { least } 10 \\
\text { days (15 } \\
\text { days for } \\
\text { TCAs and } \\
\text { MAOIs, } 2 \\
\text { months for } \\
\text { neuroleptic } \\
\text { s) }\end{array}$ & $\begin{array}{l}\text { No Axis } 1 \\
\text { disorder } \\
\text { or } \\
\text { substance } \\
\text { misuse }\end{array}$ & None & $\begin{array}{l}40 \% \text { of } \\
\text { patients } \\
\text { with } \\
\text { EUPD } \\
\text { showed } \\
\text { diffuse } \\
\text { slowing } \\
\text { on EEG }\end{array}$ & $\begin{array}{l}\text { Randomized } \\
\text { controlled } \\
\text { trial. } \\
\text { Scalp EEGs } \\
\text { recorded } \\
\text { using 17- } \\
\text { channel } \\
\text { equipment, } \\
\text { according to } \\
\text { the 10-20 } \\
\text { system. }\end{array}$ \\
\hline $\begin{array}{l}\text { Cornel } \\
\text { ius et } \\
\text { al. } \\
1986.5 \\
4\end{array}$ & DIB. ${ }^{102}$ & $\begin{array}{l}69 \\
(17 / 52)\end{array}$ & $\begin{array}{l}\text { None for at } \\
\text { least } 7 \text { days }\end{array}$ & None & $\begin{array}{l}\text { Other Axis } \\
\text { Il disorders }\end{array}$ & $\begin{array}{l}18.8 \% \\
\text { EUPD } \\
\text { patients } \\
\text { had EEG } \\
\text { dysrhyth } \\
\text { mias } \\
\text { (9.1\% } \\
\text { controls), } \\
5.8 \% \text { had } \\
\text { severe } \\
\text { EEG } \\
\text { abnormali } \\
\text { ties (0\% } \\
\text { controls), } \\
\text { but not } \\
\text { significant } \\
\text { compared } \\
\text { to } \\
\text { controls }\end{array}$ & $\begin{array}{l}\text { Case-control } \\
\text { study. Scalp } \\
\text { EEGs } \\
\text { recorded on } \\
16 \text { channel } \\
\text { instruments. } \\
\text { Electrode } \\
\text { placement } \\
\text { not } \\
\text { specified. } \\
\text { Chi-squared } \\
\text { test with } \\
\text { Yates } \\
\text { correction. }\end{array}$ \\
\hline
\end{tabular}


Snyde DSM-III (> 37

r \& 6 criteria $\quad(37 / 0)$

Pitts, ). ${ }^{103}$

1984. 5

6

( $p>0.25)$.

$\begin{array}{lll}\text { Cowdr } & \text { Clinical } & 39 \\ \text { y et } & \text { assessme } & (3 / 36) \\ \text { al. } & \text { nt } & \end{array}$

1986.5

5

Antipsycho
tics,
antidepress
ants,
anxiolytics

No axis 1
disorder

Unipolar
depression
(Research
diagnostic
criteria). ${ }^{104}$

$46 \%$

Case-control

definite study. Scalp

EEG EEGs using

abnormali 16-electrode

ties vs. placements

$10 \%$ according to

controls the 10-20

$(p=0.005)$. system with

$41 \%$

bipolar \&

EUPD monopolar

patients leads.

had

Fisher's

posterior exact test

sharp

waves vs.

$5 \%$

controls

$(p=0.005)$.

\begin{tabular}{|c|c|c|c|c|}
\hline None & None & $\begin{array}{l}\text { Dysthmic } \\
\text { disorder }\end{array}$ & $\begin{array}{l}\text { Significan } \\
\text { tly more } \\
\text { EEG } \\
\text { abnormali } \\
\text { ties in } \\
\text { those } \\
\text { with } \\
\text { EUPD } \\
\text { (38\% vs. } \\
13 \% \\
\text { controls, } \\
\text { p<0.05). } \\
\text { Increased } \\
\text { slow } \\
\text { wave } \\
\text { activity in } \\
\text { EUPD } \\
(19 \% \text { vs. } \\
3 \% \\
\text { controls, } \\
\text { p<0.05). }\end{array}$ & $\begin{array}{l}\text { Case-control } \\
\text { study. Scalp } \\
\text { EEGs with } 16 \\
\text { channels } \\
\text { using both } \\
\text { monopolar \& } \\
\text { bipolar } \\
\text { leads. } \\
\text { Electrode } \\
\text { placement } \\
\text { not } \\
\text { specified. } \\
\text { Raw Chi } \\
\text { Square for } \\
\text { analysis of } \\
\text { contingency } \\
\text { tables }\end{array}$ \\
\hline None & None & $\begin{array}{l}\text { Obsessive } \\
\text { Compulsive }\end{array}$ & $\begin{array}{l}\text { EUPD } \\
\text { patients }\end{array}$ & $\begin{array}{l}\text { Case-control } \\
\text { study. Scalp }\end{array}$ \\
\hline
\end{tabular}




\begin{tabular}{|c|c|c|c|c|c|c|c|}
\hline $\begin{array}{l}\text { et al. } \\
2008 .^{5} \\
7\end{array}$ & $(\mathrm{~F} 60.31) .^{1}$ & $(6 / 14)$ & & & $\begin{array}{l}\text { Disorder } \\
\text { Healthy } \\
\text { controls }\end{array}$ & $\begin{array}{l}\text { had a less } \\
\text { stable } \\
\text { EEG- } \\
\text { vigilance } \\
\text { pattern } \\
\text { with a } \\
\text { tendency } \\
\text { to drop to } \\
\text { lower } \\
\text { vigilance } \\
\text { states } \\
\text { ( } p=0.03 \text { ). }\end{array}$ & $\begin{array}{l}\text { EEGs with } 32 \\
\text { channels } \\
\text { according to } \\
\text { the } 10-20 \\
\text { system. } \\
\text { Artefacts } \\
\text { were } \\
\text { removed } \\
\text { following } \\
\text { visual } \\
\text { inspection. } \\
\text { ANCOVA and } \\
\text { MANCOVA }\end{array}$ \\
\hline $\begin{array}{l}\text { Van } \\
\text { Elst, } \\
2016 .{ }^{5} \\
8\end{array}$ & $\begin{array}{l}\text { SCID I and } \\
\text { II. }{ }^{100,101}\end{array}$ & $\begin{array}{l}96 \\
(3 / 93)\end{array}$ & $\begin{array}{l}\text { Antipsycho } \\
\text { tics, } \\
\text { antidepress } \\
\text { ants in } 57 \%\end{array}$ & $\begin{array}{l}\text { Affective } \\
\text { disorders, } \\
\text { eating } \\
\text { disorders, } \\
\text { ADHD, } \\
\text { substance } \\
\text { abuse }\end{array}$ & $\begin{array}{l}\text { Healthy } \\
\text { controls }\end{array}$ & $\begin{array}{l}\text { EUPD } \\
\text { patients } \\
\text { had a } \\
\text { significant } \\
\text { ly } \\
\text { increased } \\
\text { prevalenc } \\
\text { e of IRDAs } \\
\text { and IRTAs } \\
\text { (14.6\%) } \\
\text { compared } \\
\text { to HCs } \\
\text { (3.9\%) } \\
\text { p=0.02) - } \\
\text { intermitte } \\
\text { nt } \\
\text { rhythmic } \\
\text { delta or } \\
\text { theta } \\
\text { activity }\end{array}$ & $\begin{array}{l}\text { Case-control } \\
\text { study. Scalp } \\
\text { EEG with } 25 \\
\text { channels } \\
\text { according to } \\
\text { the } 10-20 \\
\text { system. } \\
\text { Pearson's } \\
\text { two-sided X2- } \\
\text { test }\end{array}$ \\
\hline $\begin{array}{l}\text { Yerev } \\
\text { anian } \\
\text { et al. } \\
1985 .^{5} \\
9\end{array}$ & $\begin{array}{l}\text { DSM- } \\
\text { III. }{ }^{103}\end{array}$ & $\begin{array}{l}29 \text { (not } \\
\text { recorde } \\
\text { d) }\end{array}$ & $\begin{array}{l}\text { Not } \\
\text { recorded }\end{array}$ & $\begin{array}{l}\text { Not } \\
\text { recorded }\end{array}$ & No controls & $\begin{array}{l}45 \% \text { of } \\
\text { EUPD } \\
\text { patients } \\
\text { had EEG } \\
\text { abnormali } \\
\text { ties, most } \\
\text { commonl } \\
\text { y in } \\
\text { temporal } \\
\text { lobe }\end{array}$ & $\begin{array}{l}\text { Cross- } \\
\text { sectional } \\
\text { study. Type } \\
\text { of EEG used } \\
\text { and } \\
\text { electrode } \\
\text { placement } \\
\text { not } \\
\text { specified. }\end{array}$ \\
\hline
\end{tabular}


TCA $=$ Tricyclic antidepressant, $\mathrm{MAOI}=$ Monoamine oxidase inhibitors, IRDA/IRTA $=$ intermittent rhythmic delta/ theta activity.

Table 4. Articles using sleep EEGs

\begin{tabular}{|c|c|c|c|c|c|c|c|}
\hline Article & $\begin{array}{l}\text { Diagn } \\
\text { ostic } \\
\text { Syste } \\
\text { m }\end{array}$ & $\begin{array}{l}\mathrm{N} \text { (male } \\
\text { /female } \\
\text { ) }\end{array}$ & $\begin{array}{l}\text { Medicati } \\
\text { ons }\end{array}$ & $\begin{array}{l}\text { Comorbid } \\
\text { conditions }\end{array}$ & $\begin{array}{l}\text { Control } \\
\text { group }\end{array}$ & Findings & $\begin{array}{l}\text { Study } \\
\text { Design/ EEG } \\
\text { type/ } \\
\text { Statistical } \\
\text { test used }\end{array}$ \\
\hline $\begin{array}{l}\text { Assad } \\
\text { et. al. } \\
2002 .{ }^{60}\end{array}$ & $\begin{array}{l}\text { ICD- } \\
10 \\
1993 .^{1}\end{array}$ & $\begin{array}{l}20 \\
(8 / 12)\end{array}$ & $\begin{array}{l}\text { None for } \\
\text { at least } 2 \\
\text { weeks } \\
\text { prior }\end{array}$ & & $\begin{array}{l}\text { Major } \\
\text { depressiv } \\
\text { e disorder } \\
\text { Healthy } \\
\text { controls }\end{array}$ & $\begin{array}{l}\text { Higher REM } \\
\% \text { ( } p<0.05) \text { \& } \\
\text { REM density } \\
\text { ( } p<0.01) \text {, } \\
\text { shorter REM } \\
\text { latency } \\
\text { ( } p<0.001) \text {, } \\
\text { longer REM } \\
\text { period } \\
\text { ( } p<0.001) \text { for } \\
\text { those with } \\
\text { EUPD than } \\
\text { controls. } \\
\text { Changes less } \\
\text { robust than } \\
\text { in those with } \\
\text { depression }\end{array}$ & $\begin{array}{l}\text { Case-control } \\
\text { study. All- } \\
\text { night } \\
\text { polysomnogr } \\
\text { aphic } \\
\text { assessments. } \\
\text { Electrode } \\
\text { placement } \\
\text { not } \\
\text { specified. } \\
\text { T-test }\end{array}$ \\
\hline $\begin{array}{l}\text { Battagli } \\
\text { a et al. } \\
1999.61\end{array}$ & $\begin{array}{l}\text { DSM- } \\
\text { III-R. }{ }^{104} \\
\text { and } \\
\text { SIDP- } \\
\text { R. }^{105}\end{array}$ & $10(4 / 6)$ & $\begin{array}{l}\text { None for } \\
\text { at least } 2 \\
\text { weeks }\end{array}$ & $\begin{array}{l}\text { Never } \\
\text { depressed, } \\
6 \text { with a } \\
\text { history of } \\
\text { alcohol or } \\
\text { drug abuse }\end{array}$ & $\begin{array}{l}\text { Healthy } \\
\text { controls }\end{array}$ & $\begin{array}{l}\text { Increased } \\
\text { REM density } \\
\text { in first REM } \\
\text { cycle in } \\
\text { those with } \\
\text { EUPD } \\
\text { compared to } \\
\text { HCs }(p<0.01)\end{array}$ & $\begin{array}{l}\text { Case-control } \\
\text { study. } \\
\text { Continuous } \\
48 \text { hour } \\
\text { ambulatory } \\
\text { EEG } \\
\text { monitoring } \\
\text { using } 3 \\
\text { channels. }\end{array}$ \\
\hline
\end{tabular}




\begin{tabular}{|c|c|c|c|c|c|c|c|}
\hline & & & & & & & $\begin{array}{l}\text { Electrode } \\
\text { placement } \\
\text { not } \\
\text { specified. } \\
\text { T-test }\end{array}$ \\
\hline $\begin{array}{l}\text { Battagli } \\
\text { a et al. } \\
1993^{62}\end{array}$ & $\begin{array}{l}\text { DSM- } \\
\text { III. }{ }^{103} \\
\& \\
\text { SIDP- } \\
\text { R. }^{105}\end{array}$ & $10(4 / 6)$ & $\begin{array}{l}\text { None for } \\
\text { at least } 2 \\
\text { weeks }\end{array}$ & $\begin{array}{l}\text { Never } \\
\text { depressed, } \\
6 \text { with } \\
\text { history of } \\
\text { drug or } \\
\text { alcohol } \\
\text { abuse }\end{array}$ & $\begin{array}{l}\text { Healthy } \\
\text { controls }\end{array}$ & $\begin{array}{l}\text { Reduced } \\
\text { REM latency } \\
\text { in those with } \\
\text { EUPD } \\
\text { compared to } \\
\text { healthy } \\
\text { controls } \\
(p<0.003)\end{array}$ & $\begin{array}{l}\text { Case-control } \\
\text { study. } \\
\text { Continuous } \\
48 \text { hour } \\
\text { ambulatory } \\
\text { EEG } \\
\text { monitoring } \\
\text { using } 3 \\
\text { channels. } \\
\text { Electrode } \\
\text { placement } \\
\text { not } \\
\text { specified. } \\
\text { T-test }\end{array}$ \\
\hline $\begin{array}{l}\text { Bell et } \\
\text { al. } \\
1983 .^{63}\end{array}$ & $\begin{array}{l}\text { DSM- } \\
\text { III. }^{103}\end{array}$ & 8 (NR) & NR & $\begin{array}{l}\text { Depression } \\
\text { in all EUPD } \\
\text { patients }\end{array}$ & $\begin{array}{l}\text { Non- } \\
\text { EUPD } \\
\text { patients } \\
\text { with } \\
\text { depressio } \\
\mathrm{n}\end{array}$ & $\begin{array}{l}\text { Reduced } \\
\text { REM latency } \\
\text { both groups, } \\
\text { EUPD } \\
\text { patients with } \\
\text { depression } \\
\text { had shorter } \\
\text { REM } \\
\text { latencies } \\
\text { than non- } \\
\text { depressed } \\
\text { EUPD } \\
\text { patients } \\
\text { (p<0.025) }\end{array}$ & $\begin{array}{l}\text { Case-control } \\
\text { study. All- } \\
\text { night } \\
\text { polysomnogr } \\
\text { aphic sleep } \\
\text { EEG. } \\
\text { Electrode } \\
\text { placement } \\
\text { not } \\
\text { specified. } \\
\text { ANCOVA }\end{array}$ \\
\hline $\begin{array}{l}\text { Mcnam } \\
\text { ara et } \\
\text { al. } \\
1984.64\end{array}$ & DIB. ${ }^{102}$ & $\begin{array}{l}10 \\
(0 / 10)\end{array}$ & $\begin{array}{l}\text { None for } \\
\text { at least } 2 \\
\text { weeks }\end{array}$ & $\begin{array}{l}\text { Depression } \\
\text { in } 6 / 10\end{array}$ & $\begin{array}{l}\text { Depressio } \\
\mathrm{n} \\
\text { Healthy } \\
\text { controls }\end{array}$ & $\begin{array}{l}\text { EUPD and } \\
\text { depressive } \\
\text { groups both } \\
\text { had Shorter } \\
\text { REM latency } \\
\text { ( } p=0.01 \text { ) and } \\
\text { increased } \\
\text { REM density }\end{array}$ & $\begin{array}{l}\text { Case-control } \\
\text { study. All } \\
\text { night } \\
\text { polysomnogr } \\
\text { aphic sleep } \\
\text { EEG, with } \\
\text { C3/A2 } \\
\text { electrode }\end{array}$ \\
\hline
\end{tabular}




\begin{tabular}{|c|c|c|c|c|c|c|c|}
\hline $\begin{array}{l}\text { Akiskal } \\
\text { et al. } \\
1985 .{ }^{65}\end{array}$ & $\begin{array}{l}\text { DSM- } \\
\text { III. }{ }^{103}\end{array}$ & $\begin{array}{l}24 \\
(12 / 12)\end{array}$ & $\begin{array}{l}\text { None for } \\
\text { at least } 2 \\
\text { weeks }\end{array}$ & $\begin{array}{l}\text { None } \\
\text { No } \\
\text { depression } \\
\text { for at least } \\
1 \text { year }\end{array}$ & $\begin{array}{l}\text { Affective } \\
\text { disorders } \\
\text { Non- } \\
\text { EUPD } \\
\text { personalit } \\
\text { y disorder } \\
\text { Healthy } \\
\text { controls }\end{array}$ & $\begin{array}{l}\text { Shorter REM } \\
\text { latency than } \\
\text { healthy } \\
\text { controls and } \\
\text { non-EUPD } \\
\text { personality } \\
\text { disorder } \\
\text { patients } \\
\text { (p<0.001), } \\
\text { but similar } \\
\text { results to } \\
\text { those with } \\
\text { affective } \\
\text { disorders }\end{array}$ & $\begin{array}{l}\text { Case-control } \\
\text { study. } \\
\text { Continuous } \\
\text { overnight } \\
\text { EEG, } \\
\text { electrode } \\
\text { placement } \\
\text { not } \\
\text { specified. } \\
\text { ANOVA and } \\
\text { when } \\
\text { significant, } \\
\text { Students t- } \\
\text { test and the } \\
\text { post-hoc } \\
\text { Scheffe test }\end{array}$ \\
\hline $\begin{array}{l}\text { Reynol } \\
\text { ds et al. } \\
1985 .{ }^{66}\end{array}$ & DIB. ${ }^{102}$ & $\begin{array}{l}20 \\
(3 / 17)\end{array}$ & $\begin{array}{l}\text { None for } \\
\text { at least } 2 \\
\text { weeks }\end{array}$ & $\begin{array}{l}\text { Depression } \\
\text { in } 10 / 20\end{array}$ & $\begin{array}{l}\text { Depressio } \\
\text { n } \\
\text { Healthy } \\
\text { controls }\end{array}$ & $\begin{array}{l}\text { Reduced } \\
\text { REM latency } \\
\text { in those with } \\
\text { EUPD } \\
\text { compared to } \\
\text { controls } \\
(p=0.02) \text {, but } \\
\text { similar to } \\
\text { those with } \\
\text { depression }\end{array}$ & $\begin{array}{l}\text { Case-control } \\
\text { study. All- } \\
\text { night EEG as } \\
\text { per C3/A2 } \\
\text { electrode } \\
\text { placement. } \\
\text { Artefacts } \\
\text { removed } \\
\text { following } \\
\text { visual } \\
\text { inspection. } \\
\text { ANOVA }\end{array}$ \\
\hline $\begin{array}{l}\text { De La } \\
\text { Fuente, } \\
2004 .{ }^{67}\end{array}$ & $\begin{array}{l}\text { DSM- } \\
\text { III-R. }{ }^{104} \\
\text { and } \\
\text { DIB. }{ }^{102}\end{array}$ & $\begin{array}{l}20 \\
(6 / 14)\end{array}$ & $\begin{array}{l}\text { None for } \\
\text { at least } \\
10 \text { days, } \\
15 \text { days } \\
\text { for TCAs } \\
\text { and } \\
\text { MAOIs } \\
\text { and no }\end{array}$ & None & $\begin{array}{l}\text { Recurrent } \\
\text { brief } \\
\text { depressio } \\
\mathrm{n} \\
\text { Major } \\
\text { depressio }\end{array}$ & $\begin{array}{l}\text { EUPD } \\
\text { patients had } \\
\text { significantly } \\
\text { less stage } 3 \\
\text { sleep and } \\
\text { slow wave } \\
\text { sleep and a } \\
\text { longer }\end{array}$ & $\begin{array}{l}\text { Case-control } \\
\text { study. } \\
\text { Overnight } \\
\text { sleep EEG } \\
\text { using } \\
\text { occipital, } \\
\text { frontal and }\end{array}$ \\
\hline
\end{tabular}




\begin{tabular}{|c|c|c|c|c|c|c|c|}
\hline & & & $\begin{array}{l}\text { antipsych } \\
\text { otics for } 2 \\
\text { months. }\end{array}$ & & $\begin{array}{l}\mathrm{n} \\
\text { Healthy } \\
\text { controls }\end{array}$ & $\begin{array}{l}\text { duration of } \\
\text { REM sleep. }\end{array}$ & $\begin{array}{l}\text { central leads. } \\
\text { ANOVA and } \\
\text { post-hoc } \\
\text { two-tailed t- } \\
\text { tests }\end{array}$ \\
\hline $\begin{array}{l}\text { De La } \\
\text { Fuente, } \\
2001 .^{68}\end{array}$ & 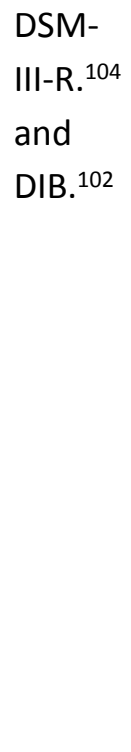 & $\begin{array}{l}20 \\
(6 / 14)\end{array}$ & $\begin{array}{l}\text { None for } \\
\text { at least } \\
10 \text { days, } \\
15 \text { days } \\
\text { or TCAs } \\
\text { and } \\
\text { MAOIs, } \\
\text { no } \\
\text { antipsych } \\
\text { otics for } 2 \\
\text { months }\end{array}$ & None & $\begin{array}{l}\text { Major } \\
\text { Depressio } \\
\mathrm{n} \\
\text { Healthy } \\
\text { controls }\end{array}$ & $\begin{array}{l}\text { EUPD } \\
\text { patients had } \\
\text { a longer } \\
\text { duration of } \\
\text { REM sleep, } \\
\text { significantly } \\
\text { less stage 3, } \\
\text { stage 4and } \\
\text { slow wave } \\
\text { sleep } \\
\text { (p<0.001) } \\
\text { than all } \\
\text { comparison } \\
\text { groups. }\end{array}$ & $\begin{array}{l}\text { Case-control } \\
\text { study. } \\
\text { Overnight } \\
\text { sleep EEG } \\
\text { using } \\
\text { occipital, } \\
\text { frontal and } \\
\text { central leads. } \\
\text { ANOVA and } \\
\text { post-hoc } \\
\text { two- tailed t- } \\
\text { tests }\end{array}$ \\
\hline $\begin{array}{l}\text { Philipse } \\
\text { n et. al. } \\
2005.69\end{array}$ & $\begin{array}{l}\text { SCID I } \\
\text { and } \\
\text { II. }{ }^{100,101}\end{array}$ & $\begin{array}{l}20 \\
(0 / 20)\end{array}$ & $\begin{array}{l}\text { None for } \\
\text { at least } 2 \\
\text { weeks } \\
\text { prior }\end{array}$ & None & $\begin{array}{l}\text { Healthy } \\
\text { controls }\end{array}$ & $\begin{array}{l}\text { No } \\
\text { significant } \\
\text { difference in } \\
\text { polysomnogr } \\
\text { ahic } \\
\text { parameters } \\
\text { Higher delta } \\
\text { power in } \\
\text { Non-REM } \\
\text { sleep for } \\
\text { those with } \\
\text { EUPD } \\
\text { (p=0.047) }\end{array}$ & $\begin{array}{l}\text { Case-control } \\
\text { study. } \\
\text { Continuous } \\
\text { overnight } \\
\text { sleep EEG } \\
\text { using C3/A2 } \\
\text { and C4/A1 } \\
\text { electrode } \\
\text { placements } \\
\text { with spectral } \\
\text { analysis. } \\
\text { MANOVAs - } \\
\text { when } \\
\text { significant } \\
\text { results found } \\
\text { ANCOVAs } \\
\text { were used }\end{array}$ \\
\hline
\end{tabular}


Table 5. Articles using evoked potentials

\begin{tabular}{|c|c|c|c|c|c|c|c|}
\hline Article & $\begin{array}{l}\text { Diagnosti } \\
\text { c System }\end{array}$ & $\begin{array}{l}\text { N (male } \\
\text { /female } \\
\text { ) }\end{array}$ & $\begin{array}{l}\text { Medication } \\
\text { s }\end{array}$ & $\begin{array}{l}\text { Comorbid } \\
\text { condition } \\
\mathrm{S}\end{array}$ & $\begin{array}{l}\text { Control } \\
\text { group }\end{array}$ & Findings & $\begin{array}{l}\text { Study Design/ } \\
\text { EEG type/ } \\
\text { Statistical test } \\
\text { used }\end{array}$ \\
\hline $\begin{array}{l}\text { Blackw } \\
\text { ood et } \\
\text { al. } \\
1986 .{ }^{70}\end{array}$ & $\begin{array}{l}\text { SADS, }{ }^{106} \\
\text { DIB, }^{102} \& \\
\text { BEFI. }^{107}\end{array}$ & $\begin{array}{l}14 \\
(0 / 14)\end{array}$ & $\begin{array}{l}\text { Lithium, } \\
\text { antidepress } \\
\text { ant, } \\
\text { tranquilizer } \\
\text { s }\end{array}$ & None & $\begin{array}{l}\text { Non- } \\
\text { EUPD } \\
\text { personal } \\
\text { ity } \\
\text { disorder } \\
\text { Healthy } \\
\text { controls }\end{array}$ & $\begin{array}{l}\text { Longer } \\
\text { P300 } \\
\text { latency } \\
\text { ( } p<0.05) \\
\text { and } \\
\text { smaller } \\
\text { amplitude } \\
\text { ( } p<0.01 \text { ) } \\
\text { in those } \\
\text { with } \\
\text { EUPD } \\
\text { than in } \\
\text { both } \\
\text { control } \\
\text { groups }\end{array}$ & $\begin{array}{l}\text { Case-control } \\
\text { study. Scalp } \\
\text { EEG via } \\
\text { electrode at Cz } \\
\text { position. } \\
\text { Artefacts } \\
\text { removed using } \\
\text { and artefact- } \\
\text { reject circuit if } \\
\text { voltage } \\
\text { exceeded } \\
45 \text { uV. Analysis } \\
\text { of variance } \\
\text { and } \\
\text { Scheffe } \\
\text { procedure }\end{array}$ \\
\hline $\begin{array}{l}\text { Kutcher } \\
\text { et al. } \\
1987 .^{71}\end{array}$ & $\begin{array}{l}\text { DSM- } \\
\mathrm{III}^{103} \\
\mathrm{DIB}^{102} \text { \& } \\
\text { BEFI. }^{107}\end{array}$ & $\begin{array}{l}22 \\
(2 / 20)\end{array}$ & $\begin{array}{l}\text { Antidepres } \\
\text { sants, } \\
\text { antipsychot } \\
\text { ics, } \\
\text { anxiolytics, } \\
\text { Lithium } \\
\text { carbonate }\end{array}$ & None & 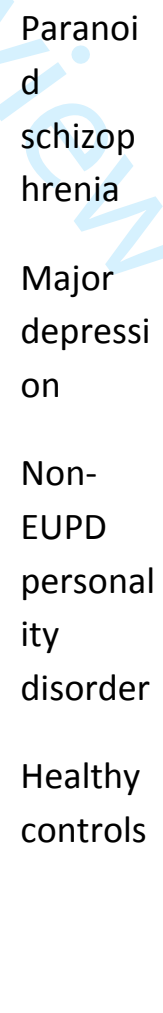 & $\begin{array}{l}\text { Decrease } \\
d \text { P300 } \\
\text { amplitude } \\
\text { ( } p=0.01 \text { ) } \\
\text { and } \\
\text { longer } \\
\text { P300 } \\
\text { latency } \\
\text { ( } p<0.01 \text { ) } \\
\text { in those } \\
\text { with } \\
\text { EUPD and } \\
\text { in those } \\
\text { with } \\
\text { schizophr } \\
\text { enia than } \\
\text { in those } \\
\text { with } \\
\text { depressio }\end{array}$ & $\begin{array}{l}\text { Case-control } \\
\text { study. Bipolar } \\
\text { EEG } \\
\text { recordings } \\
\text { using a scalp } \\
\text { electrode at } \\
\text { the Cz } \\
\text { position. } \\
\text { Artefacts } \\
\text { removed using } \\
\text { an artefact } \\
\text { reject circuit if } \\
\text { voltage } \\
\text { exceeded } \\
\text { 45uV. } \\
\text { Anova and } \\
\text { Duncan's } \\
\text { procedure }\end{array}$ \\
\hline
\end{tabular}




\begin{tabular}{|c|c|c|c|c|c|c|c|}
\hline \multirow[b]{2}{*}{$\begin{array}{l}\text { Kutcher } \\
\text { et al. } \\
1989 .{ }^{72}\end{array}$} & & & & & & $\begin{array}{l}\text { n, other } \\
\text { personalit } \\
y \\
\text { disorders } \\
\text { and } \\
\text { healthy } \\
\text { controls. }\end{array}$ & \\
\hline & $\begin{array}{l}\text { DSM- } \\
\text { III, }^{103} \\
\text { DIB, }^{102} \& \\
\text { SADS. }{ }^{106}\end{array}$ & $\begin{array}{l}23 \\
(5 / 18)\end{array}$ & $\begin{array}{l}\text { Antidepres } \\
\text { sants, } \\
\text { tranquilizer } \\
\text { s (11 drug } \\
\text { free, } 12 \\
\text { medicated) }\end{array}$ & None & $\begin{array}{l}\text { EUPD } \\
\text { with } \\
\text { schizoty } \\
\text { pal } \\
\text { personal } \\
\text { ity } \\
\text { disorder } \\
\text { (SPD) } \\
\text { Schizoty } \\
\text { pal } \\
\text { personal } \\
\text { ity } \\
\text { disorder } \\
\text { Non- } \\
\text { EUPD } \\
\text { personal } \\
\text { ity } \\
\text { disorder } \\
\text { Healthy } \\
\text { controls } \\
\text { (HC) }\end{array}$ & $\begin{array}{l}\text { Prolonged } \\
\text { P300 } \\
\text { latency } \\
\text { ( } p<0.01) \\
\text { and } \\
\text { decrease } \\
\text { d P300 } \\
\text { amplitude } \\
\text { (p<0.01) } \\
\text { in BPD } \\
\text { and in } \\
\text { SPD } \\
\text { compared } \\
\text { to other } \\
\text { personalit } \\
\text { y } \\
\text { disorders } \\
\text { and HCs }\end{array}$ & $\begin{array}{l}\text { Case-control } \\
\text { study. Bipolar } \\
\text { EEG } \\
\text { recordings } \\
\text { using a scalp } \\
\text { electrode at } \\
\text { the Cz } \\
\text { position. } \\
\text { Artefacts } \\
\text { removed using } \\
\text { an artefact } \\
\text { reject circuit if } \\
\text { voltage } \\
\text { exceeded } \\
45 u V . \\
\text { ANOVA and } \\
\text { Duncan's } \\
\text { procedure }\end{array}$ \\
\hline $\begin{array}{l}\text { Meares } \\
\text { et al. } \\
2004 . .^{73}\end{array}$ & $\begin{array}{l}\text { DSM-III- } \\
\text { R. }^{104} \text { and } \\
\text { DIB. }^{102}\end{array}$ & $\begin{array}{l}17 \\
(4 / 13)\end{array}$ & $\begin{array}{l}\text { None for at } \\
\text { least } 30 \\
\text { days }\end{array}$ & $\begin{array}{l}\text { Not } \\
\text { recorded }\end{array}$ & $\begin{array}{l}\text { Age and } \\
\text { sex- } \\
\text { matche } \\
d \\
\text { healthy } \\
\text { controls } \\
\text { Second } \\
\text { control } \\
\text { group of } \\
50 \text { men } \\
\text { and } 50 \\
\text { women } \\
\text { at }\end{array}$ & $\begin{array}{l}\text { Enhanced } \\
\text { amplitude } \\
\text { of P3a } \\
(p<0.001) \\
\text { and loss } \\
\text { of } \\
\text { temporal } \\
\text { synchroni } \\
\text { city of } \\
\text { P3a with } \\
\text { P3b in } \\
\text { BPD } \\
\text { compared }\end{array}$ & $\begin{array}{l}\text { Case-control } \\
\text { study. EEGs } \\
\text { recorded from } \\
\text { Fz, Cz \& Pz } \\
\text { electrode sites } \\
\text { according to } \\
\text { the } 10-20 \\
\text { system. } \\
\text { Artefact } \\
\text { contaminated } \\
\text { peaks } \\
\text { removed } \\
\text { below } 2 \text { \& }\end{array}$ \\
\hline
\end{tabular}




\begin{tabular}{|c|c|c|c|c|c|c|c|}
\hline & & & & & $\begin{array}{l}\text { various } \\
\text { ages as } \\
\text { normati } \\
\text { ve } \\
\text { controls }\end{array}$ & $\begin{array}{l}\text { to HCs } \\
\text { ( } p<0.01 \text { ). } \\
\text { Natural } \\
\text { age } \\
\text { related } \\
\text { decline in } \\
\text { P3a } \\
\text { amplitude } \\
\text { reduced } \\
\text { in BPD } \\
\text { ( } p<0.001 \text { ). }\end{array}$ & $\begin{array}{l}\text { above 45uV. } \\
\text { Parametric t- } \\
\text { test, } \\
\text { Non- } \\
\text { parametric } \\
\text { with Mann } \\
\text { Whitney U- } \\
\text { test. } \\
\text { Regression } \\
\text { analysis }\end{array}$ \\
\hline $\begin{array}{l}\text { Marisse } \\
\mathrm{n} \text { et al. } \\
2010 .{ }^{74}\end{array}$ & $\begin{array}{l}\text { DSM- } \\
\text { IV }^{108} \& \\
\text { SCID-II. }\end{array}$ & $\begin{array}{l}60 \\
(0 / 60)\end{array}$ & $\begin{array}{l}\text { Antidepres } \\
\text { sants, } \\
\text { antipsychot } \\
\text { ics. No } \\
\text { benzodiaze } \\
\text { pines }\end{array}$ & $\begin{array}{l}\text { No major } \\
\text { depressio } \\
\mathrm{n}, \\
\text { anxiety, } \\
\text { ADHD, } \\
\text { substance } \\
\text { abuse, } \\
\text { psychotic } \\
\text { symptom } \\
\text { s or PTSD }\end{array}$ & $\begin{array}{l}\text { Healthy } \\
\text { controls }\end{array}$ & $\begin{array}{l}\text { BPD } \\
\text { patients } \\
\text { had larger } \\
\text { LPP (late } \\
\text { positive } \\
\text { potentials } \\
\text { ) to } \\
\text { pictures } \\
\text { with an } \\
\text { unpleasa } \\
\text { nt } \\
\text { valence } \\
\text { compared } \\
\text { to } \\
\text { controls } \\
\text { ( } p<0.01 \text { ). }\end{array}$ & $\begin{array}{l}\text { Case-control } \\
\text { study. Scalp } \\
\text { EEGs recorded } \\
\text { from } 32 \\
\text { electrode sites } \\
\text { using 10-20 } \\
\text { system. } \\
\text { ANOVA and T- } \\
\text { tests }\end{array}$ \\
\hline $\begin{array}{l}\text { Drake } \\
\text { et al. } \\
1991 .{ }^{75}\end{array}$ & $\begin{array}{l}\text { DSM- } \\
\text { III. }{ }^{103}\end{array}$ & $\begin{array}{l}20 \\
(2 / 18)\end{array}$ & $\begin{array}{l}\text { None for at } \\
\text { least } 1 \\
\text { week }\end{array}$ & None & $\begin{array}{l}\text { Healthy } \\
\text { controls }\end{array}$ & $\begin{array}{l}\text { Prolonged } \\
\text { P300 } \\
\text { latency } \\
\text { ( } p<0.001 \text { ) } \\
\text { and } \\
\text { decrease } \\
\text { d P300 } \\
\text { amplitude } \\
\text { ( }<<0.001 \text { ) } \\
\text { in BPD } \\
\text { compared } \\
\text { to healthy } \\
\text { controls } \\
\text { using } \\
\text { long- }\end{array}$ & $\begin{array}{l}\text { Case-control } \\
\text { study. Scalp } \\
\text { EEGs recorded } \\
\text { from electrode } \\
\text { sites Cz, A1 \& } \\
\text { A2. } \\
\text { Two-tailed t- } \\
\text { test }\end{array}$ \\
\hline
\end{tabular}




\begin{tabular}{|c|c|c|c|c|c|c|c|}
\hline \multirow{5}{*}{$\begin{array}{l}\text { He et } \\
\text { al, } \\
2012 .{ }^{76}\end{array}$} & \multirow{4}{*}{$\begin{array}{l}\text { DSM-IV- } \\
\text { TR. }{ }^{109}\end{array}$} & \multirow{4}{*}{$\begin{array}{l}15 \\
(2 / 13)\end{array}$} & \multirow{8}{*}{$\begin{array}{l}50 \% \\
\text { prescribed } \\
\text { anxiolytics, } \\
\text { antidepress } \\
\text { ant, mood } \\
\text { stabilizers }\end{array}$} & \multirow{4}{*}{$\begin{array}{l}\text { Not } \\
\text { reported }\end{array}$} & \multicolumn{2}{|r|}{ latency } & \\
\hline & & & & & & ERPs & \\
\hline & & & & & \multirow{3}{*}{$\begin{array}{l}\text { Treatme } \\
\text { nt } \\
\text { resistan }\end{array}$} & No & \\
\hline & & & & & & difference & study. Scalp \\
\hline & & & & & & in the & EEGs recorded \\
\hline & & & & & & effect of & at electrode \\
\hline & & & & & depressi & facial & sites Fz, Cz \& \\
\hline & & & & & on & emotions & Pz. \\
\hline & & & & & (TRD) & on event & \\
\hline & & & & & & related & Multıple way \\
\hline & & & & & TRD and & potentials & ANOVA \\
\hline & & & & & BPD & in BPD & \\
\hline & & & & & Healthy & compared & \\
\hline & & & & & controls & to other & \\
\hline & & & & & & groups & \\
\hline
\end{tabular}

latency

ERPs 
Table 6. Articles meeting 3 Criteria

Articles meeting Criteria 1, 2 and 4

$\begin{array}{clllll}\text { Paper } \begin{array}{l}\text { Diagnosti } \\ \text { c System (male/ } \\ \text { female) }\end{array} & & \text { Medications } & \begin{array}{l}\text { Comorbid } \\ \text { conditions }\end{array} & \begin{array}{l}\text { Control } \\ \text { group }\end{array} & \begin{array}{c}\text { Findings } \\ \text { Study } \\ \text { design/ }\end{array} \\ & & & & \text { EEG type/ } \\ & & & \text { Statistical } \\ & & & \text { test used }\end{array}$

\begin{tabular}{|c|c|c|c|c|c|c|c|}
\hline $\begin{array}{l}\text { Housto } \\
\mathrm{n} \text { et al. } \\
2005 .{ }^{77}\end{array}$ & $\begin{array}{l}\text { SCID-II, }{ }^{101} \\
\& \\
\text { SSAGA. }{ }^{110}\end{array}$ & $61(0 / 61)$ & None & $\begin{array}{l}\text { Depression } \\
\text { Conduct } \\
\text { disorder }\end{array}$ & $\begin{array}{l}\text { EUPD - } \\
\text { free } \\
\text { adolesc } \\
\text { ents }\end{array}$ & $\begin{array}{l}\text { No age- } \\
\text { related } \\
\text { changes } \\
\text { in P300 } \\
\text { amplitu } \\
\text { de in } \\
\text { adolesc } \\
\text { ents } \\
\text { with } \\
\text { EUPD } \\
\text { (p<0.05) }\end{array}$ & $\begin{array}{l}\text { Case- } \\
\text { control } \\
\text { study. } \\
\text { Scalp EEG } \\
\text { recorded at } \\
31 \\
\text { electrode } \\
\text { sites. } \\
\text { Artefacts } \\
\text { removed } \\
\text { using an } \\
\text { algorithm. } \\
\text { ANCOVA }\end{array}$ \\
\hline $\begin{array}{l}\text { Housto } \\
n \text { et al. } \\
2004 .{ }^{78}\end{array}$ & $\begin{array}{l}\text { SCID-II, }{ }^{101} \\
\& \\
\text { SSAGA. }{ }^{110}\end{array}$ & $\begin{array}{l}88 \text { (not } \\
\text { reported) }\end{array}$ & None & $\begin{array}{l}\text { No } \\
\text { Schizophre } \\
\text { nia or } \\
\text { Bipolar } \\
\text { Disorder, } \\
\text { otherwise } \\
\text { not } \\
\text { reported }\end{array}$ & $\begin{array}{l}\text { EUPD- } \\
\text { free } \\
\text { adolesc } \\
\text { ents }\end{array}$ & $\begin{array}{l}\text { Reduce } \\
d \text { P300 } \\
\text { amplitu } \\
\text { de in } \\
\text { those } \\
\text { with } \\
\text { EUPD } \\
\text { ( } p<0.05 \text { ) }\end{array}$ & $\begin{array}{l}\text { Case- } \\
\text { control } \\
\text { study. } \\
\text { Scalp EEG } \\
\text { recorded at } \\
31 \\
\text { electrode } \\
\text { sites. } \\
\text { Artefacts } \\
\text { removed } \\
\text { using an } \\
\text { algorithm. } \\
\text { Repeated } \\
\text { measures } \\
\text { analysis of } \\
\text { variance }\end{array}$ \\
\hline
\end{tabular}




\begin{tabular}{|c|c|c|c|c|c|c|c|}
\hline $\begin{array}{l}\text { Archer } \\
\text { et al. } \\
1988 .{ }^{79}\end{array}$ & $\begin{array}{l}\text { DSM- } \\
\text { III. }{ }^{103}\end{array}$ & $\begin{array}{l}16 \text { (not } \\
\text { reported) }\end{array}$ & $\begin{array}{l}\text { Psychotropic } \\
\text { drug free } \\
\text { (time } \\
\text { without } \\
\text { medications } \\
\text { not } \\
\text { reported) }\end{array}$ & None & $\begin{array}{l}\text { Non- } \\
\text { EUPD } \\
\text { personal } \\
\text { ity } \\
\text { disorder } \\
\text { Dysthmi } \\
\text { c } \\
\text { Disorder } \\
\text { Other } \\
\text { psychiat } \\
\text { ric } \\
\text { diagnosi } \\
\text { s }\end{array}$ & $\begin{array}{l}\text { No } \\
\text { significa } \\
\mathrm{nt} \\
\text { differen } \\
\text { ce } \\
\text { betwee } \\
\mathrm{n} \\
\text { groups }\end{array}$ & $\begin{array}{l}\text { Case- } \\
\text { control } \\
\text { study. } \\
\text { Scalp EEG } \\
\text { both } \\
\text { waking \& } \\
\text { sleeping. } \\
\text { Electrode } \\
\text { placement } \\
\text { not } \\
\text { specified. } \\
\text { Fisher's } \\
\text { exact test }\end{array}$ \\
\hline
\end{tabular}


Table 7. Articles meeting 3 Criteria

Articles meeting criteria 1, 2 and 3

\begin{tabular}{|c|c|c|c|c|c|c|c|}
\hline Paper & $\begin{array}{l}\text { Diagnosti } \\
\text { c System }\end{array}$ & $\begin{array}{l}\mathrm{N} \text { (male } \\
\text { /female) }\end{array}$ & $\begin{array}{l}\text { Medication } \\
\mathrm{s}\end{array}$ & $\begin{array}{l}\text { Comorbid } \\
\text { conditions }\end{array}$ & $\begin{array}{l}\text { Control } \\
\text { group }\end{array}$ & Findings & $\begin{array}{l}\text { Study } \\
\text { Design/ } \\
\text { EEG type/ } \\
\text { Statistical } \\
\text { test used }\end{array}$ \\
\hline $\begin{array}{l}\text { Schaaff } \\
\text { et al. } \\
2007.80\end{array}$ & $\begin{array}{l}\text { DSM- } \\
\text { III. }^{103}\end{array}$ & $9(0 / 0)$ & $\begin{array}{l}\text { Unmedicat } \\
\text { ed \& drug- } \\
\text { naive }\end{array}$ & $\begin{array}{l}\text { Not } \\
\text { reported }\end{array}$ & $\begin{array}{l}\text { Healthy } \\
\text { controls }\end{array}$ & $\begin{array}{l}\text { Significan } \\
\text { tly higher } \\
\text { loudness } \\
\text { dependen } \\
\text { ce of the } \\
\mathrm{N} 1 / \mathrm{P} 2 \\
\text { compone } \\
\text { nt of } \\
\text { auditory } \\
\text { evoked } \\
\text { potentials } \\
\text { in } \\
\text { patients } \\
\text { with } \\
\text { EUPD } \\
\text { compared } \\
\text { to healthy } \\
\text { controls } \\
\text { ( } p<0.05 \text { ) }\end{array}$ & $\begin{array}{l}\text { Case- } \\
\text { control } \\
\text { study. } \\
\text { Scalp EEGs } \\
\text { using } 32 \\
\text { electrodes } \\
\text { according } \\
\text { to the } \\
\text { 10/10 } \\
\text { system. } \\
\text { Only } \\
\text { artefact } \\
\text { free } \\
\text { sweeps } \\
\text { were } \\
\text { collected. } \\
\text { T-tests and } \\
\text { Mann } \\
\text { Whitney U } \\
\text { tests }\end{array}$ \\
\hline $\begin{array}{l}\text { William } \\
\text { s et al. } \\
2006 .{ }^{81}\end{array}$ & ICD-10. ${ }^{1}$ & $15(4 / 11)$ & None & None & $\begin{array}{l}\text { Healthy } \\
\text { controls }\end{array}$ & $\begin{array}{l}\text { EUPD } \\
\text { patients } \\
\text { showed a } \\
\text { significant } \\
\text { delay in } \\
\text { early } \\
\text { posterior } \\
\text { gamma } \\
\text { synchrony } \\
\text { ( } p=0.02 \text { ) }\end{array}$ & $\begin{array}{l}\text { Case- } \\
\text { control } \\
\text { study. } \\
\text { Scalp EEG } \\
\text { using } 19 \\
\text { electrodes } \\
\text { according } \\
\text { to the } \\
10 / 10 \\
\text { system. }\end{array}$ \\
\hline
\end{tabular}




\begin{tabular}{|c|c|c|c|c|c|c|c|}
\hline & & & & & & $\begin{array}{l}\& \\
\text { reduced } \\
\text { right } \\
\text { hemisphe } \\
\text { re late } \\
\text { gamma } \\
\text { synchrony } \\
\text { (p=0.02) } \\
\text { compared } \\
\text { with } \\
\text { healthy } \\
\text { controls }\end{array}$ & $\begin{array}{l}\text { Artefacts } \\
\text { removed } \\
\text { manually } \\
\text { following } \\
\text { visual } \\
\text { inspection. } \\
\text { ANOVA }\end{array}$ \\
\hline $\begin{array}{l}\text { Corneli } \\
\text { us et al. } \\
1988 .^{82}\end{array}$ & $\begin{array}{l}\text { DIB, }{ }^{102} \& \\
\text { SADS. }{ }^{106}\end{array}$ & $17(7 / 10)$ & $\begin{array}{l}\text { Medication } \\
\text { free for at } \\
\text { least one } \\
\text { week } \\
\text { (medicatio } \\
\text { ns } \\
\text { discontinue } \\
\text { d not } \\
\text { reported) }\end{array}$ & None & None & $\begin{array}{l}\text { Mean } \\
\text { frequency } \\
\text { on } \\
\text { spectral } \\
\text { analysis } \\
\text { correlate } \\
\text { d with } \\
\text { anxiety } \\
\text { levels in } \\
\text { patients } \\
\text { with } \\
\text { EUPD ( } P= \\
0.033 \text { to } \\
0.052 \text { ) } \\
\text { after } \\
\text { placebo } \\
\text { and } \\
\text { ampheta } \\
\text { mine } \\
\text { challenge }\end{array}$ & $\begin{array}{l}\text { Clinical } \\
\text { trial. Scalp } \\
\text { EEGs with } \\
\text { 16-channel } \\
\text { recordings } \\
\text { with } \\
\text { electrodes } \\
\text { according } \\
\text { to the 10- } \\
20 \text { system. } \\
\text { Pearson } \\
\text { correlation } \\
\text { coefficients }\end{array}$ \\
\hline $\begin{array}{l}\text { De La } \\
\text { Fuente } \\
\text { et al. } \\
2011.83\end{array}$ & $\begin{array}{l}\text { DSM III- } \\
\mathrm{R}^{104} \\
\mathrm{DIB}^{102} \text { \& } \\
\text { SADS. }{ }^{106}\end{array}$ & $20(6 / 14)$ & $\begin{array}{l}\text { Medication } \\
\text { wash-out } \\
\text { period of at } \\
\text { least } 10 \\
\text { days (15 } \\
\text { days for } \\
\text { TCAs, } \\
\text { benzodiaze } \\
\text { pines } \\
\text { \&MAOIs, } 2 \\
\text { months for }\end{array}$ & None & None & $\begin{array}{l}\text { TSH and } \\
\text { standard } \\
\text { EEG } \\
\text { results } \\
\text { influence } \\
\text { sleep } \\
\text { EEG, } \\
\text { neurologi } \\
\text { c soft } \\
\text { signs and } \\
\text { post }\end{array}$ & $\begin{array}{l}\text { Cohort } \\
\text { study. } \\
\text { Scalp wake } \\
\text { and sleep } \\
\text { EEGs. EEG } \\
\text { type \& } \\
\text { electrode } \\
\text { placement } \\
\text { not } \\
\text { specified. } \\
\text { Bayesian }\end{array}$ \\
\hline
\end{tabular}




\begin{tabular}{|c|c|c|c|c|c|c|c|}
\hline & & & $\begin{array}{l}\text { neuroleptic } \\
\text { s) }\end{array}$ & & & $\begin{array}{l}\text { dexameth } \\
\text { asone } \\
\text { cortisol in } \\
\text { patients } \\
\text { with } \\
\text { EUPD }\end{array}$ & $\begin{array}{l}\text { network } \\
\text { model }\end{array}$ \\
\hline $\begin{array}{l}\text { Ruchso } \\
\text { w et al. } \\
2008 .{ }^{84}\end{array}$ & SCID-II. ${ }^{101}$ & $17(1 / 16)$ & $\begin{array}{l}\text { Not } \\
\text { reported }\end{array}$ & None & $\begin{array}{l}\text { Healthy } \\
\text { controls }\end{array}$ & $\begin{array}{l}\text { When } \\
\text { performin } \\
\text { g a Go } \\
\text { Nogo } \\
\text { task, } \\
\text { those } \\
\text { with } \\
\text { EUPD had } \\
\text { reduced } \\
\text { P3 } \\
\text { amplitude } \\
\text { s during } \\
\text { Nogo } \\
\text { responses } \\
\text { compared } \\
\text { to healthy } \\
\text { controls } \\
\text { ( } p<0.04 \text { ) }\end{array}$ & 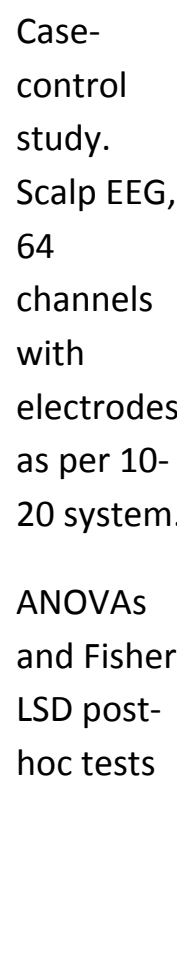 \\
\hline $\begin{array}{l}\text { Vega et } \\
\text { al. } \\
2017 .{ }^{85}\end{array}$ & $\begin{array}{l}\text { DSM- } \\
\text { IV, }{ }^{108} \\
\text { DIB, }^{102} \& \\
\text { SCID-II. }\end{array}$ & $40(0 / 40)$ & $\begin{array}{l}\text { Antidepres } \\
\text { sants, } \\
\text { antipsychot } \\
\text { ics, mood } \\
\text { stabilizers, } \\
\text { benzodiaze } \\
\text { pines }\end{array}$ & None & $\begin{array}{l}\text { Healthy } \\
\text { controls } \\
\text { EUPD } \\
\text { patients } \\
\text { without } \\
\text { a history } \\
\text { of non- } \\
\text { suicidal } \\
\text { self- } \\
\text { injury } \\
\text { (NSSI) }\end{array}$ & $\begin{array}{l}\text { EUPD } \\
\text { patients } \\
\text { with NSSI } \\
\text { exhibited } \\
\text { enhanced } \\
\text { activation } \\
\text { of the } \\
\text { orbitofro } \\
\text { ntal } \\
\text { cortex } \\
\text { following } \\
\text { an } \\
\text { unexpect } \\
\text { ed reward } \\
\text { compared } \\
\text { to healthy } \\
\text { controls } \\
\text { and EUPD } \\
\text { patients }\end{array}$ & $\begin{array}{l}\text { Case- } \\
\text { control } \\
\text { study. } \\
\text { Functional } \\
\text { MRI. No } \\
\text { EEGs. } \\
\text { Anova and } \\
\text { F-test }\end{array}$ \\
\hline
\end{tabular}


without

NSSI

$(p<0.05)$

Table 8. Articles meeting 3 Criteria.

Articles meeting criteria 1, 3 and 4

\begin{tabular}{|c|c|c|c|c|c|c|c|}
\hline Paper & $\begin{array}{l}\text { Diagnostic } \\
\text { System }\end{array}$ & $\begin{array}{l}\mathbf{N} \text { (male } \\
\text { /female) }\end{array}$ & Medications & $\begin{array}{l}\text { Comorbid } \\
\text { conditions }\end{array}$ & $\begin{array}{l}\text { Control } \\
\text { group }\end{array}$ & Findings & $\begin{array}{l}\text { Study } \\
\text { Design/ } \\
\text { EEG type/ } \\
\text { Statistical } \\
\text { test used }\end{array}$ \\
\hline
\end{tabular}

54
5
56
57
58
59

\begin{tabular}{|c|c|c|c|c|c|c|c|}
\hline $\begin{array}{l}\text { Cohen } \\
\text { et al. } \\
2016.86\end{array}$ & $\begin{array}{l}\text { SCID-II'101 \& } \\
\text { MCMI.[130] }\end{array}$ & $1(0 / 1)$ & $\begin{array}{l}\text { Not } \\
\text { reported }\end{array}$ & $\begin{array}{l}\text { Not } \\
\text { reported }\end{array}$ & None & $\begin{array}{l}\text { Mild to } \\
\text { moderate } \\
\text { increase in } \\
\text { slow wave } \\
\text { frequencies }\end{array}$ & $\begin{array}{l}\text { Case } \\
\text { study. } \\
\text { QEEG - } 19 \\
\text { sensor } \\
\text { instrument }\end{array}$ \\
\hline
\end{tabular}




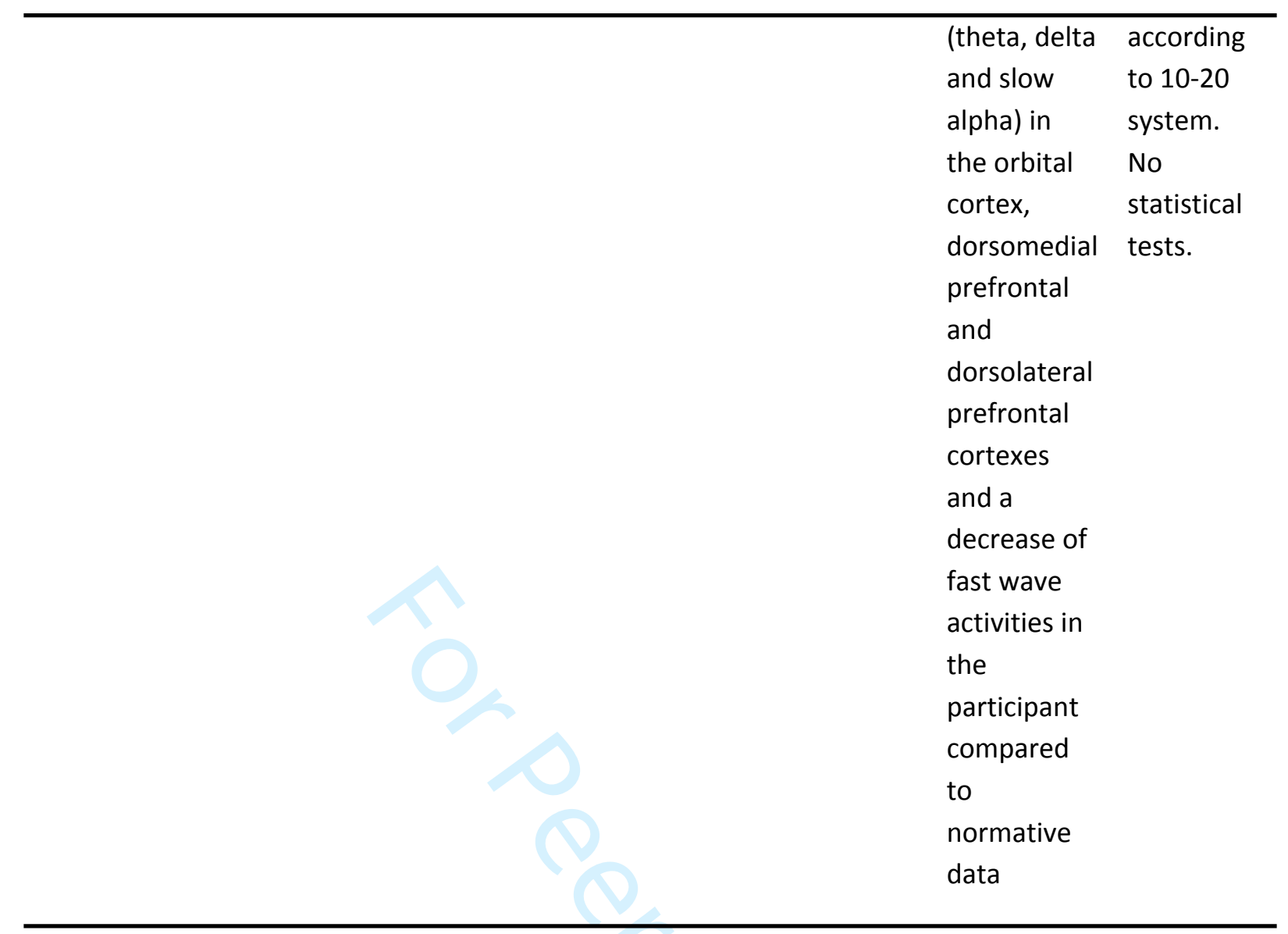


Table 9. Articles meeting 3 Criteria.

Articles meeting criteria 2, 3 and 4

\begin{tabular}{|c|c|c|c|c|c|c|c|}
\hline Paper & $\begin{array}{l}\text { Diagnosti } \\
\text { c System }\end{array}$ & $\begin{array}{l}\mathrm{N} \\
\text { (male } \\
\text { /femal } \\
\text { e) }\end{array}$ & $\begin{array}{l}\text { Medication } \\
\text { s }\end{array}$ & $\begin{array}{l}\text { Comorbid } \\
\text { condition } \\
\text { s }\end{array}$ & $\begin{array}{l}\text { Control } \\
\text { group }\end{array}$ & Findings & $\begin{array}{l}\text { Study design/ } \\
\text { EEG type/ } \\
\text { Statistical test } \\
\text { used }\end{array}$ \\
\hline $\begin{array}{l}\text { Teiche } \\
\text { r et al. } \\
1997 .{ }^{3} \\
4\end{array}$ & $\begin{array}{l}\text { History of } \\
\text { abuse }\end{array}$ & $\begin{array}{l}15 \\
(7 / 8)\end{array}$ & $\begin{array}{l}\text { Not } \\
\text { reported }\end{array}$ & $\begin{array}{l}\text { Not } \\
\text { reported }\end{array}$ & $\begin{array}{l}\text { Healthy } \\
\text { controls }\end{array}$ & $\begin{array}{l}\text { Children } \\
\text { with a } \\
\text { history of } \\
\text { abuse had } \\
\text { greater } \\
\text { average left } \\
\text { hemispher } \\
\text { e } \\
\text { coherence } \\
\text { than } \\
\text { controls } \\
\text { ( } p=0.007 \text { ) } \\
\text { and a } \\
\text { greater } \\
\text { number of } \\
\text { abnormal } \\
\text { EEGs } \\
\text { ( } p=0.021 \text { ) }\end{array}$ & $\begin{array}{l}\text { Case-control } \\
\text { study. EEG } \\
\text { type \& } \\
\text { electrode } \\
\text { placement not } \\
\text { specified. } \\
\text { Analysis of } \\
\text { variance and } \\
\text { two-tailed t- } \\
\text { test }\end{array}$ \\
\hline $\begin{array}{l}\text { Brazie } \\
\text { r et al. } \\
1945 .^{8} \\
8\end{array}$ & $\begin{array}{l}\text { Clinical } \\
\text { examinati } \\
\text { on }\end{array}$ & $\begin{array}{l}100 \\
(43 / 57 \\
)\end{array}$ & $\begin{array}{l}\text { Not } \\
\text { reported }\end{array}$ & None & $\begin{array}{l}\text { Healthy } \\
\text { controls }\end{array}$ & $\begin{array}{l}\text { Higher } \\
\text { incidence } \\
\text { of beta } \\
\text { activity in } \\
\text { psychoneur } \\
\text { osis versus } \\
\text { controls } \\
\text { (critical } \\
\text { ratio 6.54) }\end{array}$ & $\begin{array}{l}\text { Case-control } \\
\text { study. Scalp } \\
\text { EEG at bipolar } \\
\text { occipital leads. } \\
\text { Artefacts } \\
\text { removed } \\
\text { following } \\
\text { visual } \\
\text { inspection. } \\
\text { Chi Square } \\
\text { and critical } \\
\text { ratio }\end{array}$ \\
\hline
\end{tabular}




\begin{tabular}{|c|c|c|c|c|c|c|c|}
\hline $\begin{array}{l}\text { Xu et } \\
\text { al. } \\
2014 .^{8} \\
9\end{array}$ & $\begin{array}{l}\text { DSM-IV- } \\
\text { TR.[128] }\end{array}$ & $\begin{array}{l}21 \\
(0 / 21)\end{array}$ & $\begin{array}{l}\text { Not } \\
\text { reported }\end{array}$ & None & $\begin{array}{l}\text { Healthy } \\
\text { controls } \\
\text { Treatmen } \\
\mathrm{t} \\
\text { Resistant } \\
\text { Depressio } \\
\mathrm{n} \text { (TRD) } \\
\text { Generaliz } \\
\text { ed } \\
\text { Anxiety } \\
\text { Disorder } \\
\text { (GAD) }\end{array}$ & $\begin{array}{l}\text { Reduced P3 } \\
\text { amplitude } \\
\text { in those } \\
\text { with TRD \& } \\
\text { GAD } \\
\text { compared } \\
\text { to healthy } \\
\text { controls } \\
\text { and those } \\
\text { with EUPD } \\
\text { ( } p<0.05 \text { ) }\end{array}$ & $\begin{array}{l}\text { Case-control } \\
\text { study. Scalp } \\
\text { EEGs with } \\
\text { electrodes at } \\
\text { midline Fz, Cz } \\
\text { \& Pz sites. } \\
\text { Only artefact- } \\
\text { free sweeps } \\
\text { were included } \\
\text { Multivariate } \\
\text { analysis of } \\
\text { variance and } \\
\text { post hoc } \\
\text { analysis by } \\
\text { least } \\
\text { significant } \\
\text { difference test }\end{array}$ \\
\hline $\begin{array}{l}\text { Hill et } \\
\text { al. } \\
2005.9 \\
0\end{array}$ & $\begin{array}{l}\text { McLean } \\
\text { screening } \\
\text { instrume } \\
\text { nt }^{92}\end{array}$ & $\begin{array}{l}15 \\
(0 / 15)\end{array}$ & $\begin{array}{l}\text { Antidepres } \\
\text { sants }\end{array}$ & $\begin{array}{l}\text { Depressio } \\
\mathrm{n}\end{array}$ & $\begin{array}{l}\text { Healthy } \\
\text { controls }\end{array}$ & $\begin{array}{l}\text { Those with } \\
\text { EUPD traits } \\
\text { had smaller } \\
\text { LPC } \\
\text { amplitude } \\
\text { ( } p<0.02 \text { ), } \\
\text { P300 } \\
\text { latency } \\
\text { (P<0.05) } \\
\text { and P300 } \\
\text { amplitudes } \\
\text { ( } p=0.08 \text { ) } \\
\text { when } \\
\text { making } \\
\text { incorrect } \\
\text { responses } \\
\text { to } \\
\text { emotional } \\
\text { pictures } \\
\text { and faces }\end{array}$ & $\begin{array}{l}\text { Case-control } \\
\text { study. Scalp } \\
\text { EEG with } 16 \\
\text { electrodes } \\
\text { according to } \\
\text { the } 10-20 \\
\text { system. } \\
\text { ANOVAs }\end{array}$ \\
\hline $\begin{array}{l}\text { Shen } \\
\text { et al. } \\
2008 .^{9}\end{array}$ & $\begin{array}{l}\text { DSM-IV- } \\
\text { TR }^{109} \& \\
\text { Parker } \\
\text { Personalit }\end{array}$ & $\begin{array}{l}18 \\
(0 / 18)\end{array}$ & $\begin{array}{l}\text { Anxiolytics } \\
\text { Antidepres } \\
\text { sants }\end{array}$ & None & $\begin{array}{l}\text { Healthy } \\
\text { controls } \\
\text { Non- }\end{array}$ & $\begin{array}{l}\text { No } \\
\text { significant } \\
\text { difference } \\
\text { in ERPs }\end{array}$ & $\begin{array}{l}\text { Case-control } \\
\text { study. Scalp } \\
\text { EEGs with } \\
\text { electrodes }\end{array}$ \\
\hline
\end{tabular}




\begin{tabular}{|c|c|c|c|c|}
\hline 1 & $\begin{array}{l}\text { y } \\
\text { Measur. }{ }^{11} \\
1\end{array}$ & $\begin{array}{l}\text { EUPD } \\
\text { personalit } \\
\text { y disorder }\end{array}$ & $\begin{array}{l}\text { between } \\
\text { those with } \\
\text { EUPD and } \\
\text { other } \\
\text { groups }\end{array}$ & $\begin{array}{l}\text { placed at } \\
\text { midline Fz, Cz } \\
\text { \& Pz. Traces } \\
\text { with artefact } \\
\text { automatically } \\
\text { rejected } \\
\text { following } \\
\text { visual } \\
\text { inspection. } \\
\text { ANOVAs and } \\
\text { post hoc } \\
\text { analysis by } \\
\text { Duncan's } \\
\text { multiple new } \\
\text { range test }\end{array}$ \\
\hline
\end{tabular}

Table 10. Articles meeting 3 Criteria.

Articles meeting criteria 2, 4 and 5

\begin{tabular}{|c|c|c|c|c|c|c|c|}
\hline Paper & $\begin{array}{l}\text { Diagnostic } \\
\text { System }\end{array}$ & $\begin{array}{l}\text { N (male } \\
\text { /female } \\
\text { ) }\end{array}$ & Medications & $\begin{array}{l}\text { Comorbi } \\
\text { d } \\
\text { condition } \\
\text { S }\end{array}$ & $\begin{array}{l}\text { Contro } \\
\text { I } \\
\text { group }\end{array}$ & Findings & $\begin{array}{l}\text { Study } \\
\text { design/ } \\
\text { Statistica } \\
\text { I test } \\
\text { used }\end{array}$ \\
\hline $\begin{array}{l}\text { Huang- } \\
\text { Storms } \\
\text { et al. } \\
2006 .[41 \\
\text { ] }\end{array}$ & $\begin{array}{l}\text { Children } \\
\text { with } \\
\text { histories } \\
\text { of abuse } \\
\text { or neglect, } \\
\text { many with } \\
\text { a diagnosis } \\
\text { of Reactive } \\
\text { Attachmen } \\
\text { t Disorder } \\
\text { (RAD) }\end{array}$ & $\begin{array}{l}20 \\
(9 / 11)\end{array}$ & $\begin{array}{l}\text { SSRIs } \\
\text { Amphetamine } \\
\mathrm{S} \\
\text { Atomoxetine } \\
\text { Ziprasidone } \\
\text { Risperidone }\end{array}$ & $\begin{array}{l}\text { None } \\
\text { reported }\end{array}$ & None & $\begin{array}{l}\text { Improvement } \\
\text { in score on } \\
\text { the Child } \\
\text { Behaviour } \\
\text { Checklist (95) } \\
\text { following } \\
\text { qEEG-guided } \\
\text { neurofeedbac } \\
k \text { ( }<<0.05)\end{array}$ & $\begin{array}{l}\text { Clinical } \\
\text { trial. } \\
\text { QEEG } \\
\text { with } 19 \\
\text { scalp } \\
\text { electrode } \\
\text { s as per } \\
10-20 \\
\text { system. } \\
\text { Two- } \\
\text { tailed } \\
\text { paired t- }\end{array}$ \\
\hline
\end{tabular}


Table 11.

\section{Abnormalities found on standard EEGs in EUPD}

1. Posterior sharp waves. [55]

2. Increased slow wave activity.[56]

3. Less stable EEG vigilance patterns.[57]

4. Increased prevalence of intermittent rhythmic delta \& theta activity[58]

5. Delay in early posterior gamma synchrony $\&$ a reduction in right hemisphere late gamma synchrony in response to salient stimuli[83]

Table 12.

\begin{tabular}{|l|l|l|}
\hline Embase & Final Search & 2817 \\
\hline Psyclnfo & Final Search & 1123 \\
\hline Medline & Final Search & 1310 \\
\hline NHS Evidence & Final Search & 0 \\
\hline Cochrane & Final Search & 0 \\
\hline JB & Final Search & 0 \\
\hline Open Grey & Final Search & 1 \\
\hline Clinical Trials & Final Search & 6 \\
\hline UK Clinical Trials gateway & Final Search & 0 \\
\hline EU Clinical Trials Register & Final Search & 0 \\
\hline
\end{tabular}

